\title{
DESIGN APPROACH FOR RECTANGULAR MUDMATS UNDER FULLY THREE-DIMENSIONAL LOADING
}

\author{
X. Feng ${ }^{1}$, M. F. Randolph ${ }^{1}$, S. Gourvenec ${ }^{1}$ and R. Wallerand ${ }^{2}$
}

Published in Géotechnique 64(1): 51-63. http://dx.doi.org/10.1680/geot.13.P.051

\author{
${ }^{1}$ Xiaowei FENG \\ Centre for Offshore Foundation Systems - M053 \\ University of Western Australia \\ 35 Stirling Highway, Crawley \\ Perth, WA 6009 \\ Australia \\ Tel: +61 864882473 \\ Fax: +61 864881044 \\ Email: xiaowei.feng@uwa.edu.au

\section{${ }^{1}$ Mark F. RANDOLPH} \\ Centre for Offshore Foundation Systems \\ University of Western Australia \\ Tel: +61 864883075 \\ Email: mark.randolph@uwa.edu.au

\section{Susan GOURVENEC} \\ Centre for Offshore Foundation Systems \\ University of Western Australia \\ Tel: +61 864883094 \\ Email: susan.gourvenec@uwa.edu.au
}

\section{${ }^{2}$ Régis WALLERAND}

Subsea7

Paris

Tel: +33 140979007

Email: regis.wallerand@subsea7.com

No. of words: 4985 (without abstract and references)

No. of tables: 3

No. of figures: 23 


\title{
Design approach for rectangular mudmats under fully three-dimensional loading
}

\author{
X. Feng ${ }^{1}$, M.F. Randolph ${ }^{1}$, S. Gourvenec ${ }^{1}$, R.Wallerand ${ }^{2}$
}

\begin{abstract}
Mudmats are used in the offshore oil and gas industry to support subsea infrastructure for pipeline terminations and well manifolds. Expansion and contraction of connected pipelines and jumpers due to changing thermal and pressure conditions impose fully three-dimensional loading on the foundations, dominated by horizontal, moment and torsional loading rather than high vertical loads. The mudmat foundations are rectangular, and include shallow skirts in order to increase capacity, particularly for sliding. Offshore design guidelines for shallow foundations tend to excessive conservatism; optimisation of mudmat capacity under general loading has thus become critical in order to keep foundation footprints within the limits of current installation vessels. The paper presents an alternative design methodology, based on failure envelopes derived from an extensive programme of three-dimensional finite element analyses, focusing on the sliding and rotational capacity of the foundation. Starting from expressions that quantify the uniaxial capacity under each of the six degrees of freedom, failure envelope shapes for different biaxial combinations are developed. Ultimately, the allowable capacity under the six degree of freedom loading is expressed in terms of a twodimensional failure envelope for the resultant horizontal and moment loading, after due allowance for the vertical and torsional components of load.
\end{abstract}

\section{KEYWORDS}

Bearing capacity; clays; design; failure; footings/foundations; numerical modelling

\footnotetext{
${ }^{1}$ Centre for Offshore Foundation Systems, The University of Western Australia

2 Subsea 7, Paris
} 


\section{INTRODUCTION}

The increasing focus on deep water developments in the offshore industry has led to renewed interest in the design of shallow foundations, often referred to as mudmats, or mat foundations. Mudmats, which have been used historically to provide temporary stability for fixed jacket platforms in relatively shallow water, are now widely employed for deep water subsea production infrastructure, such as manifolds, end terminations and in-line structures for pipelines. Operational loads can be complex and three-dimensional due to thermal expansion and contraction of connecting pipelines and jumpers, with significant moment and torsional components of load. By contrast, the vertical loading is static and typically small in comparison with the bearing capacity. The magnitude of the applied loading is such that the size of mudmats is now reaching the limit that can be installed by moderate-sized vessels such as used for pipe-laying, and there is a strong incentive to develop robust but accurate design methods in order to optimise the foundation size.

Conventional design approaches, as embodied in industry design approaches such as ISO (2003) and API (2011), focus on the vertical bearing capacity but modified due to the applied horizontal and moment loading. The underlying solutions are those for plane strain conditions (Prandtl, 1921; Davis and Booker, 1973), to which semi-empirical factors are applied to account for foundation shape, load inclination and eccentricity (Meyerhof, 1953; Brinch Hansen, 1970). The design approach is based on the conservative assumption of no tensile stresses being sustainable beneath the (skirted) foundation, and further conservatism arises for practical load combinations from the simple linear superposition of separate solutions for load inclination and eccentricity (Gourvenec, 2007).

Alternative approaches based on failure envelopes in vertical, horizontal and moment (V-HM) loading space have been derived for shallow foundations of various geometries, including strip, circular and rectangular, using either upper and lower bound plasticity analysis (e.g. Houlsby and Puzrin, 1999; Bransby and Randolph, 1998, 1999; Randolph and Puzrin 2003; Salgado et al., 2004) or finite element analyses (e.g. Taiebat and Carter, 2000, 2002, 2010; Gourvenec and Randolph, 2003; Gourvenec, 2007, 2008; Gourvenec and Barnett, 2011; Bransby and Yun, 2009). A summary of the scope of these various contributions was provided by Randolph (2012).

Amongst most of the documented results, a typical assumption is that the combined vertical load (V), horizontal load (H) and moment (M) applied to the structure act in a single vertical plane. In addition, torsional loading (T) has tended to be ignored, or limited to its effect in 
reducing either the bearing capacity in the absence of lateral loading (Finnie and Morgan, 2004) or the sliding capacity (Yun et al., 2009; Murff et al., 2010). In practice, mudmats for subsea structures (but also shallow foundations in general) are subjected to fully threedimensional, six degree-of-freedom, loading. While the resulting foundation response may be assessed on a case-by-case basis using three-dimensional finite element analysis, initial design studies require much simpler approaches where changes in mudmat geometry or loading conditions can be investigated efficiently.

The paper describes such an approach, leading ultimately to algebraic expressions for a failure envelope in the two-dimensional loading space of resultant moment and resultant horizontal load, for different magnitudes of vertical load and torsion. Although the approach may be applied more generally, detailed results are restricted here to the conditions shown in Figure 1 , where a rectangular skirted foundation rests on a deep clay layer where the strength may be idealised as increasing linearly with depth. The mudmat is acted on by fully three-dimensional loading, involving vertical dead load (self-weight) $\mathrm{V}$, biaxial live horizontal loads, $\mathrm{H}_{\mathrm{x}}, \mathrm{H}_{\mathrm{y}}$, moments $\mathrm{M}_{\mathrm{y}}, \mathrm{M}_{\mathrm{x}}$ and torque $\mathrm{T}$, loading (referred to here as $\mathrm{V}-\mathrm{H}^{2}-\mathrm{M}^{2}-\mathrm{T}$ loading). The sign conventions follow those suggested by Butterfield et al. (1997). The mudmat geometry is focused on those typically adopted for subsea systems, with aspect ratio, B/L, of about 0.5 and skirt depth ratios, $d / B$, up to 0.2 . The load reference point is taken at the coordinate origin, at the surface of the soil, as typically assumed during design.

\section{OVERALL STRATEGY}

The overall strategy adopted for simplifying the problem was influenced by typical design conditions, whereby the vertical load is essentially static and failure is generally governed by sliding (including torsion) or overturning. The main steps in the approach, which are discussed sequentially in the following sections, are summarised in Table 1 . The overall size of the failure envelope is dictated by the extreme points, represented by the 'uniaxial' capacities where a single component of load or moment acts on the foundation. Twodimensional slices of the failure envelope are then considered, with the uniaxial capacities due to horizontal, moment and torsional loading reduced according to the magnitude of the applied vertical load. Maximum resultant horizontal and moment capacities are evaluated, according to the angle (in plan view) of the resultant loading (see Figure 2), leading to a twodimensional failure envelope in (resultant) $\mathrm{H}-\mathrm{M}$ space. The final failure envelope is then obtained by adjusting the maximum values, $\mathrm{H}_{\max }$ and $\mathrm{M}_{\max }$, according to the magnitude of torsion to be sustained by the foundation. Note that, although $\mathrm{M}_{\mathrm{y}}$ will generally be negative, 
according to the right hand axis convention, for ease of comparisons in the results presented later it is taken as a positive quantity, reversing its sign.

The overall strategy will be illustrated in an example at the end of the paper. However, the main focus of the paper is to document the results of extensive three-dimensional finite element analyses undertaken in order to derive generic values for the uniaxial capacities and the various two-dimensional failure envelopes required to verify the full six degree-offreedom interaction. The results are strictly applicable only to the shallowly embedded rectangular foundation geometry and linearly varying soil strength profile considered, although the underlying methodology has wider applicability.

\section{FINITE ELEMENT ANALYSES}

\section{Geometry and meshes}

All of the finite element analyses were conducted using the software ABAQUS (Dassault Systèmes, 2010). The problem modelled is as shown in Figure 1. Rectangular foundations of breadth $\mathrm{B}$, length $\mathrm{L}$, and embedment depth $\mathrm{d}$ were considered. The foundation was modelled as a solid rigid plug on the assumption that sufficient internal skirts would be provided (in reality) that the confined soil plug would displace rigidly. The majority of the analyses targeted a typical aspect ratio of $\mathrm{B} / \mathrm{L}=0.5$, although sensitivity studies were undertaken within the range $0.33 \leq B / L \leq 1$. The skirt depth ratio $d / B$ was varied from zero to 0.2 , again encompassing typical skirt depths, which in many cases are less than 0.1. Actual mudmat dimensions are generally restricted to widths of 5 to $10 \mathrm{~m}$, and lengths of up to $20 \mathrm{~m}$, depending on vessel configurations, but results are presented here in non-dimensional form.

The finite element meshes were extended 3B from the edges of the mudmat and 3B beneath the mudmat, with fully constrained nodes at the base, and horizontally constrained nodes at the sides, sufficiently remote that the failure loads were not affected by the boundary conditions. Various different mesh densities were investigated to achieve a time-efficient model without compromising the accuracy. The typical example shown in Figure 3 comprised approximately 28,000 8-node linear brick, hybrid elements.

\section{Material properties and interface conditions}

The material response under undrained soil conditions was represented with a linear elastic perfectly plastic constitutive law according to a Tresca failure criterion. Only undrained conditions were considered (with Poisson's ratio set to 0.49 ) and the soil shear strength was 
assumed to vary linearly with depth, $z$, according to $s_{u}=s_{u m}+k z$, where $s_{u m}$ is the shear strength at mudline $(\mathrm{z}=0)$ and $\mathrm{k}$ is the shear strength gradient (Figure 1). The degree of strength heterogeneity is expressed by the ratio $\kappa=\mathrm{kB} / \mathrm{s}_{\mathrm{u} 0}$, where $\mathrm{s}_{\mathrm{u} 0}$ is the shear strength at skirt tip level, considering values ranging from 0 (uniform) to 10. A constant rigidity index of $\mathrm{G} / \mathrm{s}_{\mathrm{u}}=333$ was adopted, ensuring failure at small deformations and thus minimising mesh distortion. With this choice of rigidity index the displacements when the corresponding ultimate capacities were approached were observed to be less than 0.03B for vertical loading and $0.01 \mathrm{~B}$ for horizontal loading. The submerged unit weight of the soil was taken as $\gamma^{\prime}=6 \mathrm{kN} / \mathrm{m}^{3}$, so that $\gamma^{\prime} \mathrm{d} / \mathrm{su}_{\mathrm{u}, \text { avg }}$ was maintained equal to 1.2 (for all $\kappa$ values) for the deepest skirt considered of $\mathrm{d}=1 \mathrm{~m}$.

The mudmat was modelled as a discrete rigid body, embedded to a depth, d, with the underside of the topcap aligned with mudline level and the interface between the mudmat base and the subsoil was fully bonded, i.e. rough in shear with no detachment permitted. The contact properties between the vertical mudmat sides and the surrounding soil were taken as frictionless with separation allowed (zero tension condition). This choice was governed by the wish to obtain conservative values of capacity for embedded foundations, notwithstanding the assumption of tensile stresses allowed at the foundation base. Further discussion of the influence of the contact properties is provided later the paper. Depending on particular design loads and durations, this would need to be checked, but typical unfactored loading conditions do not lead to tensile stresses on the foundation base (e.g. Gaudin et al., 2012; Dimmock et al., 2013).

\section{Methodology}

Failure envelopes under combined loading conditions were evaluated using two separate techniques:

(a) Displacement-controlled 'swipe' loading paths, as introduced in physical model tests by Tan (1990) and which have been shown to follow the failure envelopes closely for surface foundations in V-H and V-M load spaces (Gourvenec \& Randolph, 2003; Gourvenec, 2008).

(b) Fixed ratio probe tests, both displacement-controlled and load-controlled (e.g. Bransby and Randolph, 1998; Taiebat and Carter, 2002; Gourvenec \& Randolph 2003; Bienen et al., 2006; Yun and Bransby, 2007; Gourvenec 2008). 
Swipe tests can provide extended sections of the failure envelope from a single analysis, but tend to undercut the true failure envelopes when foundations are embedded (Gourvenec, 2008). Probe tests are more intensive computationally since they provide only a single point on the failure envelope, particularly under load-control where very small load increments are necessary as failure is approached in order not to overshoot the failure envelope. Using both approaches in combination provided robust estimates of the failure envelopes.

\section{RESULTS}

\section{Pure uniaxial capacity}

Uniaxial vertical capacity. Effects of soil heterogeneity on undrained vertical bearing capacity have been investigated for strip and circular foundations (Davis and Booker, 1973; Houlsby and Wroth, 1983), but there are no published solutions for rectangular foundations embedded in heterogeneous soil. For surface foundations on homogeneous soil, the undrained vertical bearing capacity factor reduces gradually as the aspect ratio, $\mathrm{B} / \mathrm{L}$, reduces, with the value for $\mathrm{B} / \mathrm{L}=0.5$ being close to mid-way between those for circular and strip foundations (Salgado et al., 2004; Gourvenec et al., 2006). However, as the degree of strength heterogeneity increases, the shape factor relative to a strip foundation reduces, becoming less than unity for values of $\kappa$ less than about 2 . For $B / L=0.5$, it was found that purely vertical capacities for embedded rectangular foundations may be expressed as:

$$
\frac{\mathrm{V}_{\mathrm{ult}}}{\mathrm{As}_{\mathrm{u} 0}}=5.7\left(1+0.234 \tanh \left(4.78 \frac{\mathrm{d}}{\mathrm{B}}\right)\right)\left(1+0.2 \kappa-0.012 \kappa^{2}+0.0004 \kappa^{3}\right)
$$

The quality of fit to the finite element results is shown in Figure 4. Some analyses (not shown) were conducted for slightly greater embedment, up to $d / B=0.3$, and indicated that the depth factor remained accurate but this has not been explored fully, or for deeper embedment.

Uniaxial horizontal capacity. The horizontal capacity is dominated by the translational sliding resistance at skirt tip level, which is the product of the base area, A, and the shear strength at that level, $\mathrm{s}_{\mathrm{u} 0}$. For an embedded foundation, there is an additional net contribution from the active and passive earth pressures on the mudmat skirts, which can be estimated as a bearing factor $\mathrm{N}_{\mathrm{p}}$ times the shear strength at the mid-depth of the skirts (Bransby and Randolph, 1999). If the soil remains attached to (or collapses against) the active (rear) edge of the foundation, there is no effect of the soil self-weight, since work done against the self-weight balances out on the passive (front) and active (rear) skirts. When detachment at the active side 
occurs (for low ratios of self-weight stress to shear strength) the mechanism becomes asymmetric, with a single soil wedge pushed up at the passive side. The soil-self weight then affects the $\mathrm{N}_{\mathrm{p}}$ factor.

The horizontal capacities parallel to the $\mathrm{x}$ and $\mathrm{y}$ axes may be expressed as

$$
\begin{aligned}
& \frac{\mathrm{H}_{\text {xult }}}{\mathrm{As}_{\mathrm{u} 0}}=1+\frac{\mathrm{d}}{\mathrm{B}}\left(\mathrm{N}_{\mathrm{p}}+2 \alpha_{\text {skirt }} \frac{\mathrm{B}}{\mathrm{L}}\right)\left(1-\frac{\kappa}{2} \frac{\mathrm{d}}{\mathrm{B}}\right) \\
& \frac{\mathrm{H}_{\text {yult }}}{\mathrm{As}_{\mathrm{u} 0}}=1+\frac{\mathrm{d}}{\mathrm{B}}\left(\mathrm{N}_{\mathrm{p}} \frac{\mathrm{B}}{\mathrm{L}}+2 \alpha_{\text {skirt }}\right)\left(1-\frac{\kappa}{2} \frac{\mathrm{d}}{\mathrm{B}}\right)
\end{aligned}
$$

Friction on the side skirts has been allowed for in the above expression, through the friction ratio of $\alpha_{\text {skirt, }}$ even though this was taken as zero in the finite element analyses. The finite element results (allowing for up to $9 \%$ discrepancy) are fitted reasonably using a skirt bearing factor of $\mathrm{N}_{\mathrm{p}}=2.2+\gamma^{\prime} \mathrm{d} / 2 \mathrm{~s}_{\mathrm{u} \text {,avg }} \leq 4.4$ for smooth skirts and $\mathrm{N}_{\mathrm{p}}=4.4$ for fully rough skirts (see Figure 5) where $\mathrm{s}_{\mathrm{u}, \mathrm{avg}}$ is the shear strength at the mid-depth of the skirts.

Uniaxial moment capacity. Exact solutions for the moment capacity of surface strip (with width B) and circular foundations (with diameter $\mathrm{D}$ ) are $\mathrm{M}_{\mathrm{ult}}=0.69 \mathrm{~B}^{2} \mathrm{~S}_{\mathrm{u} 0}$ and $\mathrm{M}_{\mathrm{ult}}=0.67 \mathrm{ADs}_{\mathrm{u} 0}$ respectively (Randolph and Puzrin, 2003). Shape factors for surface rectangular foundations on homogenous soil, assuming a fully bonded soil interface (no tensile failure), have been estimated based on finite element analysis (Gourvenec, 2007), leading to

$$
\frac{\mathrm{M}_{\text {ult,rectangular }}}{\mathrm{M}_{\text {ult,strip }}}=1+0.22 \frac{\mathrm{B}}{\mathrm{L}}
$$

This would give $\mathrm{M}_{\text {yult }} / \mathrm{ABs}_{\mathrm{u} 0}=0.77$ and $\mathrm{M}_{\mathrm{xult}} / \mathrm{ALs}_{\mathrm{u} 0}=0.99$ for $\mathrm{B} / \mathrm{L}=0.5$.

Finite element analysis of a surface strip foundation on homogeneous soil gave $\mathrm{M}_{\mathrm{ult}}=$ $0.72 \mathrm{~B}^{2} \mathrm{~S}_{\mathrm{u} 0}$ for the meshes used in the present work, suggesting a numerical error of about $4 \%$. For the rectangular mudmat (with $\mathrm{B} / \mathrm{L}=0.5$ ), the corresponding finite element results were $\mathrm{M}_{\text {yult }} / \mathrm{ABs}_{\mathrm{u} 0}=0.84$ and $\mathrm{M}_{\mathrm{xult}} / \mathrm{ALs}_{\mathrm{u} 0}=1.04$. Reducing these by 4 or $5 \%$ would then give reasonable agreement with the values quoted above based on the moment capacity shape factor.

Following a similar pattern as for $\mathrm{V}_{\text {ult }}$ the numerical values of uniaxial moment capacity were fitted by 


$$
\begin{aligned}
& \frac{\mathrm{M}_{\text {yult }}}{\mathrm{ABs}_{\mathrm{u} 0}}=0.84\left(1+0.254 \tanh \left(4.51 \frac{\mathrm{d}}{\mathrm{B}}\right)\right)\left(1+0.2 \kappa-0.01 \kappa^{2}+0.0004 \kappa^{3}\right) \\
& \frac{\mathrm{M}_{\mathrm{xult}}}{\mathrm{ALs}_{\mathrm{u} 0}}=1.04\left(1+0.124 \tanh \left(8.31 \frac{\mathrm{d}}{\mathrm{B}}\right)\right)\left(1+0.3 \kappa-0.028 \kappa^{2}+0.00134 \kappa^{3}\right)
\end{aligned}
$$

These provide a good fit at each embedment depth ratio, as indicated in Figure 6. For application, it is suggested to reduce the leading coefficients to 0.79 and 0.99 respectively. As for vertical loading, the expressions for the depth factor appear accurate up to at least $\mathrm{d} / \mathrm{B}=0.3$ but should be used with caution for deeper embedment.

Uniaxial torsional capacity. Pure torsional resistance of a surface foundation can be calculated by integrating the shear strength across the base area. An exact solution has been presented by Murff et al. (2010) and an approximate relationship as a function of the aspect ratio, B/L, by Finnie and Morgan (2004), expressed respectively as:

$$
\begin{aligned}
\frac{\mathrm{T}_{\mathrm{ult}}}{\mathrm{ALs}_{\mathrm{u} 0}} & =\frac{4}{\mathrm{AL}} \int_{0}^{\mathrm{B} / 2} \int_{0}^{\mathrm{L} / 2} \sqrt{\mathrm{x}^{2}+\mathrm{y}^{2}} \mathrm{dxdy} \\
& =\frac{\mathrm{L}}{6 \mathrm{~B}}\left(\frac{\sin \theta_{0}}{2 \cos ^{2} \theta_{0}}+0.5 \ln \left(\tan \left(\frac{\pi}{4}+\frac{\theta_{0}}{2}\right)\right)\right)+\frac{\mathrm{B}^{2}}{6 \mathrm{~L}^{2}}\left(\frac{\cos \theta_{0}}{2 \sin \theta_{0}}-0.5 \ln \left(\tan \frac{\theta_{0}}{2}\right)\right) \\
& \approx 0.25+0.04 \frac{\mathrm{B}}{\mathrm{L}}+0.09\left(\frac{\mathrm{B}}{\mathrm{L}}\right)^{2}
\end{aligned}
$$

where, $\theta_{0}=\arctan (\mathrm{B} / \mathrm{L})$. For a mudmat with aspect ratio $\mathrm{B} / \mathrm{L}=0.5$, the torsional capacity can be calculated as $\mathrm{T}_{\mathrm{ult}} / \mathrm{ALs}_{\mathrm{u} 0}=0.297$ (or 0.29 from the approximate relationship). The 3-D finite element analysis gave $\mathrm{T}_{\mathrm{ult}} / \mathrm{ALs}_{\mathrm{u} 0}=0.317$, an error of just under $7 \%$.

The additional torsional capacity from the skirts may be estimated in much the same way as that of horizontal capacity, assuming a net passive resistance factor of $\mathrm{N}_{\mathrm{p}}$ from skirts on opposite sides of the foundation, to give

$$
\frac{\Delta \mathrm{T}_{\mathrm{ult}}}{\mathrm{ALs}_{\mathrm{u} 0}}=\frac{\mathrm{d}}{\mathrm{B}}\left[\frac{\mathrm{N}_{\mathrm{p}}}{4}\left(1+\left(\frac{\mathrm{B}}{\mathrm{L}}\right)^{2}\right)+1.4 \alpha_{\text {skirt }} \frac{\mathrm{B}}{\mathrm{L}}\right]\left(1-\frac{\kappa}{2} \frac{\mathrm{d}}{\mathrm{B}}\right)
$$

A reasonable fit to the finite element results is obtained using a value of $\mathrm{N}_{\mathrm{p}}=2.5+\gamma^{\prime} \mathrm{d} / 2 \mathrm{~s}_{\mathrm{u}, \mathrm{avg}} \leq 5.0$ for smooth skirts and $\mathrm{N}_{\mathrm{p}}=5.0$ for fully rough skirts as shown in Figure 7. The slight divergence for the deepest embedment ratio is most probably a result of increasing numerical error. 


\section{Failure envelopes for biaxial loading planes including V}

Vertical and horizontal loading plane. The shape of failure envelopes in vertical and horizontal load space $(\mathrm{M}=\mathrm{T}=0)$ generally follows the plane strain plasticity solution proposed by Green (1954). Previous studies on surface strip and circular foundations have shown that, when normalised by the ultimate loads, all the failure envelopes fall in a very tight band for deposits with any linearly varying shear strength distribution, i.e. different $\kappa$ value (Gourvenec and Randolph, 2003). For the rectangular foundation considered here, normalised failure envelopes, with $\mathrm{V}$ and $\mathrm{H}$ normalised by their ultimate values as $\mathrm{v}=\mathrm{V} / \mathrm{V}_{\text {ult, }}$, $\mathrm{h}=\mathrm{H}_{\mathrm{x}} / \mathrm{H}_{\text {xult }}$ (for loading angle $\theta=0$ ) or $\mathrm{h}=\mathrm{H}_{\mathrm{y}} / \mathrm{H}_{\text {yult }}\left(\right.$ for $\theta=90^{\circ}$ ), may be approximated as

$$
\begin{array}{ll}
\text { For } \mathrm{v} \leq 0.5 & \mathrm{~h}=1 \\
\text { For } \mathrm{h}<1 & \mathrm{v}=0.5+0.5 \sqrt{1-\mathrm{h}^{2.5-\cos ^{2} \theta}}
\end{array}
$$

A comparison of this expression with the finite element results is shown in Figure 8. Some data points fall a little inside the envelope, particularly as $\mathrm{d} / \mathrm{B}$ increases, and this may be compensated for by slight adjustment of the coefficients to give a failure envelope of

For $\mathrm{v} \leq 0.4 \quad \mathrm{~h}=1$

For $\mathrm{h}<1 \quad \mathrm{v}=0.4-0.6 \sqrt{1-\mathrm{h}^{2.5-\cos ^{2} \theta}}$

Vertical and moment loading plane. The failure envelopes in normalised V-M space $(\mathrm{H}=\mathrm{T}=0)$ derived from the finite element results may be fitted reasonably accurately by a simple power law curve of the form (Gourvenec and Randolph, 2003)

$$
\mathrm{V}=(1-\mathrm{m})^{\mathrm{p}}
$$

The exponent $\mathrm{p}$ was found to range from 0.23 to 0.43 for a strip foundation, as $\kappa$ increased from 0 to 10 . The value of $\mathrm{p}$ changes with the shape of foundation, and a simple quadratic function for a rectangular foundation of $\mathrm{B} / \mathrm{L}$ has been proposed previously for homogeneous soil (Gourvenec, 2007). The value of p also depends on the degree of strength heterogeneity, and again this can be expressed as a polynomial function of $\kappa$.

For moment loading about the long axis (i.e. the $\mathrm{V}-\mathrm{M}_{\mathrm{y}}$ plane), close fits were obtained for an exponent given by

$$
\mathrm{p}=0.23\left(1+0.19 \kappa-0.02 \kappa^{2}+0.001 \kappa^{3}\right)\left[1+0.4 \frac{\mathrm{B}}{\mathrm{L}}-0.1\left(\frac{\mathrm{B}}{\mathrm{L}}\right)^{2}\right]
$$


essentially independent of the embedment ratio. For moment loading about the short axis (V-Mx plane) the same expression can be used, but replacing $\mathrm{B} / \mathrm{L}$ by $\mathrm{L} / \mathrm{B}$.

A synthesis of all data were plotted, irrespective of the strength heterogeneity, by taking the $(1 / p)^{\text {th }}$ root of Equation (9), and then plotting the linear relationship of $\mathrm{v}^{1 / \mathrm{p}}$ against normalised moment, $m$. These fits are shown for the $V-M_{y}$ and $V-M_{x}$ planes in Figure 9. In both cases, the maximum error is extremely small and only data for surface foundations $(d / B=0)$ fall inside the proposed failure envelopes.

Vertical and torsional loading plane. Under combined vertical and torsional loading $(\mathrm{H}=\mathrm{M}=0)$, the finite element results fit a failure envelope similar to that for $\mathrm{V}-\mathrm{H}$ loading. $\mathrm{A}$ single expression provides an adequate (and mostly conservative) fit, given by

$$
\begin{array}{ll}
\text { For } \mathrm{v} \leq 0.5 & \mathrm{t}=1 \\
\text { For } \mathrm{t}<1 & \mathrm{v}=0.5+0.5 \sqrt{1-\mathrm{t}^{2.5}}
\end{array}
$$

The quality of the fit is illustrated in Figure 10.

\section{Resultant horizontal and moment capacities}

The ultimate horizontal capacity in any direction, denoted as $\mathrm{H}_{\mathrm{ult}}$, can be explored on a plot of $\mathrm{H}_{\mathrm{x}}-\mathrm{H}_{\mathrm{y}}$ by carrying out analyses for different ratios of $\mathrm{H}_{\mathrm{x}} / \mathrm{H}_{\mathrm{y}}$. The failure envelope expands and changes shape slightly with increasing embedment ratio (as shown in Figure 11), but the shape is not affected significantly by the degree of soil heterogeneity. A general expression for the failure envelope, taking account of the embedment ratio, can be expressed as

$$
\left(\frac{\mathrm{H}_{\mathrm{x}}}{\mathrm{H}_{\text {xult }}}\right)^{2+6 \frac{\mathrm{d}}{\mathrm{B}}}+\left(\frac{\mathrm{H}_{\mathrm{y}}}{\mathrm{H}_{\text {yult }}}\right)^{2}=1 \text { for } 0 \leq \kappa \leq 10 ; \mathrm{V} / \mathrm{V}_{\text {ult }} \leq 0.5 ; \mathrm{M}=\mathrm{T}=0
$$

For a surface mudmat, the limiting horizontal load in any direction theoretically satisfies $\mathrm{H}_{\mathrm{ult}}=\mathrm{As}_{\mathrm{u} 0}$ and the failure envelope in $\mathrm{H}_{\mathrm{x}}-\mathrm{H}_{\mathrm{y}}$ plane should be circular, which Equation (12) reverts to. The expression is essentially accurate for low levels of vertical load ( $\mathrm{V} / \mathrm{V}_{\mathrm{ult}} \leq 0.5$ ), where the failure mechanism for combined vertical and horizontal loading is one of sliding. An example normalised $\mathrm{H}_{\mathrm{x}}-\mathrm{H}_{\mathrm{y}}$ failure envelope for a surface foundation is shown in Figure 12 to verify the applicability of Equation (12) within the proposed range of vertical load. However, within the overall methodology, it is also applied for larger vertical loads, with the values of $\mathrm{H}_{\text {xult }}$ and $\mathrm{H}_{\text {yult }}$ adjusted according to Equation 8. The maximum resultant horizontal load, $\mathrm{H}_{\mathrm{ult}}$, may be deduced from that equation for any given angle of loading (or ratio, $\mathrm{H}_{\mathrm{x}} / \mathrm{H}_{\mathrm{y}}$ ). 
A similar generalised ellipse may also be used to fit the failure envelopes in the $M_{y}-M_{x}$ plane. For moment loading the shape of the ellipse was found to be essentially independent of the embedment ratio, but contracted inward as the degree of soil heterogeneity increased. A generalised form may be expressed as (Figure 13 \& Figure 14)

$$
\left(\frac{M_{y}}{M_{\text {yult }}}\right)^{1.5}+\left(\frac{M_{x}}{M_{\text {xult }}}\right)^{3-0.1 \kappa}=1 \quad \mathrm{~V}=\mathrm{H}=\mathrm{T}=0
$$

\section{Torsion effects on VMH failure envelopes}

Torsion will effectively reduce the maximum horizontal load or moment that can be sustained by the soil. Torsional effects on horizontal capacity were explored by conducting a series of load-controlled finite element analyses. Combined horizontal-torsional (H-T) action was realised by applying the load at an eccentricity $\mathrm{e}_{\mathrm{T}}$ from the centreline of the foundation and direction of the resultant horizontal load was controlled by the ratio of $\mathrm{H}_{\mathrm{x}} / \mathrm{H}_{\mathrm{y}}$. The failure envelopes are plotted in Figure 15. Different eccentricities for the horizontal components (i.e. $\mathrm{e}_{\mathrm{Tx}} \neq \mathrm{e}_{\mathrm{Ty}}$ ) were also investigated, but the effect on the $\mathrm{H}-\mathrm{T}$ failure envelopes was found to be insignificant. The main reason is that the resultant torsion is always along the $\mathrm{z}$-axis, meaning that verifying eccentricities for the horizontal components just changes the gradient of the $\mathrm{H}-\mathrm{T}$ load path for a given $\mathrm{H}_{\mathrm{x}} / \mathrm{H}_{\mathrm{y}}$. Therefore, the $\mathrm{H}-\mathrm{T}$ load combination at failure should fall on the same failure envelope as that produced by the given $\mathrm{H}_{\mathrm{x}}, \mathrm{H}_{\mathrm{y}}$ with identical $\mathrm{e}_{\mathrm{T}}$.

It can be observed from Figure 15 that the normalised failure envelope is smallest when $\mathrm{H}$ is applied along the short axis and it extends outwards gradually as the horizontal loading direction changes from $0^{\circ}$ to $90^{\circ}$. Hence, for a given magnitude of $\mathrm{H} / \mathrm{H}_{\mathrm{ult}}$, higher torsional resistance is available when the horizontal load acts parallel to the long side of the mudmat.

The failure envelopes from finite element analysis were fitted by the general proposed relationship between torsion and horizontal load (Finnie and Morgan, 2004), expressed as

$$
\left(\frac{\mathrm{H}}{\mathrm{H}_{\mathrm{ult}}}\right)^{\mathrm{m}}+\left(\frac{\mathrm{T}}{\mathrm{T}_{\mathrm{ult}}}\right)^{\mathrm{n}}=1 \text { for } \mathrm{V}=\mathrm{M}=0
$$

For a rectangular foundation, the power $\mathrm{m}$ ranges from 1 to 2 and $\mathrm{n}$ from 2 to 2.5. Contrary to Finnie and Morgan (2004), the investigation by Yun et al. (2009) on the basis of finite element results demonstrated that m varies from 1.9 to 2.02 and $n$ from 0.95 to 1.84 . In this study, general expressions have been derived for the powers $\mathrm{m}$ and $\mathrm{n}$ : 


$$
\begin{aligned}
& \mathrm{m}=1.85 \\
& \mathrm{n}=1.25+0.75(\sin \theta)^{2.5}
\end{aligned}
$$

The resulting envelopes are compared with the finite element results in Figure 15. The power for the torque term changes from $n=1.25$ for horizontal loading parallel to the latitude axis of the foundation, to $\mathrm{n}=2$ for loading parallel to the longitude axis, which are reasonably close to those suggested by Yun et al. (2009). It was found that the failure envelopes were essentially insensitive to either the soil heterogeneity factor, $\kappa$, or the embedment ratio, $d / B$, as illustrated in Figure 16. For loading parallel to the long axis of the foundation $\left(\theta=90^{\circ}\right)$, the expression for the failure envelope becomes increasingly conservative for low levels of torsion as the embedment depth increases. More accurate envelopes can be obtained by keeping $m$ unchanged but adjusting $n$ to

$$
\mathrm{n}=1.25+\left(0.75+2.5 \frac{\mathrm{d}}{\mathrm{B}}\right)(\sin \theta)^{2.5(1+5 \mathrm{~d} / \mathrm{B}))}
$$

Normalised moment-torsion, M-T, failure envelopes (Figure 17) were also explored for surface and shallowly embedded mudmats and soil with different degrees of shear strength heterogeneity. A general equation was developed to estimate the M-T failure envelopes, which were found to be independent of moment direction $\left(\theta_{\mathrm{m}}\right)$, foundation embedment depth and soil heterogeneity factor. The failure envelope can be expressed as:

$$
\left(\frac{\mathrm{M}}{\mathrm{M}_{\mathrm{ult}}}\right)^{6}+\left(\frac{\mathrm{T}}{\mathrm{T}_{\mathrm{ult}}}\right)^{2}=1
$$

\section{Combined M-H failure envelopes}

The yield envelopes expressed by Equations (14) to (17) are used to deduce the maximum resultant horizontal load, $\mathrm{H}_{\max }$, and moment, $\mathrm{M}_{\max }$, corresponding to a given mobilisation of torsional capacity. The final stage is then to consider the failure envelope in momenthorizontal load space.

Although from a design perspective it is convenient to take the load reference point (LRP) at the mudline, it was found that the M-H failure envelopes become effectively independent of the embedment ratio if the LRP is taken at skirt tip level, that is by substituting a moment of $\mathrm{M}^{*}=\mathrm{M}+\mathrm{Hd}$, but without changing $\mathrm{H}_{\max }$ (which would also be affected by the position of the LRP). An example of the effect of this transformation on the shape of failure envelopes is 
illustrated in Figure 18. The failure envelopes are, however, still affected by the degree of soil heterogeneity (Figure 19) and the direction of the resultant horizontal load (Figure 20).

Analyses were carried out for horizontal load directions of $0^{\circ}$ (i.e. parallel to B), $30^{\circ}, 45^{\circ}, 60^{\circ}$ and $90^{\circ}$ (i.e. parallel to L), and for soil heterogeneity factors of $\kappa=0,0.5,1,2,5$ and 10 . These led to approximate failure envelopes expressed as

$$
\left(\frac{M^{*}}{M_{\max }} \frac{M^{*}}{\left|M^{*}\right|}\right)^{q}\left(1-\alpha \frac{H}{H_{\max }} \frac{M^{*}}{\left|M^{*}\right|}+\beta\left(\frac{H}{H_{\max }}\right)^{2}\right)+\left(\frac{H}{H_{\max }}\right)^{2}=1
$$

where, the power, $\mathrm{q}$, and coefficients $\alpha$ and $\beta$ are functions of the direction of the resultant horizontal loading, expressed as an angle $\theta$ from the $\mathrm{x}$-axis, and of the soil strength heterogeneity, $\kappa$. They may be approximated as:

$$
\begin{aligned}
& q=3(1+\kappa / 10) \\
& \alpha=0.3\left(3+\frac{\kappa}{10}\left(\cos ^{2} \theta-2 \sin ^{2} \theta\right)\right) \\
& \beta=0.09 \kappa
\end{aligned}
$$

Comparisons of the failure envelope fits provided by these expressions with the results from FE analysis are shown in Figure 21 for various values of soil strength heterogeneity factor, $\kappa$, and embedment ratio, $\mathrm{d} / \mathrm{B}$, and zero torque (so $\mathrm{H}_{\max }=\mathrm{H}_{\mathrm{ult}}$ and $\mathrm{M}_{\max }=\mathrm{M}_{\mathrm{ult}}$ in Equation (18))

Finally, Figure 22 shows comparisons of the failure envelope fits for different levels of torsion. The results are for surface mudmats, but various combinations of soil strength heterogeneity factor, $\kappa$, and loading direction, $\theta$. The proposed failure envelopes from Equations (18) and (19) provide reasonable, and slightly conservative, fits to the FE results.

\section{EXAMPLE APPLICATION}

An example application is considered here, showing how the proposed methodology may be used in design. The input data for the problem are summarised in Table 2, comprising foundation geometry, shear strength profile and (factored) design loads. In a design problem, the size of the mudmat would be varied in order to optimise the design, with the required reserve strength ratio, or material factor applied to the soil shear strength. Here, the material factor is evaluated for the given mudmat size. The calculations were performed following the 
design steps summarised in Table 1, as detailed below including the relevant equations and figures.

Step 1: From input parameters in Table 2 values of $\mathrm{s}_{\mathrm{u} 0}=\mathrm{s}_{\mathrm{um}}+\mathrm{kd}$ and non-dimensional quantities B/L, d/B and $\kappa=k B / s_{u 0}$ are evaluated (see Figure 1).

Step 2: Uniaxial capacities for vertical, horizontal, moment and torsional loading are calculated from Equations (1), (2), (4), (5) and (6), and Figure 4, Figure 5, Figure 6 and Figure 7. The uniaxial capacities are tabulated in Table 3. The critical modes of loading are in torsion and sliding.

Step 3: The ultimate horizontal and moment values are adjusted to account for the vertical load mobilisation through Equations (7) and (9), and Figure 8 and Figure 9.

Step 4: For the given angle of resultant horizontal load $\left(\theta=\arctan \left(\mathrm{H}_{\mathrm{y}} / \mathrm{H}_{\mathrm{x}}\right)\right.$ and that of resultant moment $\left(\theta_{\mathrm{m}}=\arctan \left(\mathrm{M}_{\mathrm{y}} / \mathrm{M}_{\mathrm{x}}\right)\right.$, the corresponding ultimate horizontal capacity is evaluated from Equation (12) and Figure 11, and the ultimate moment capacity through Equation (13) and Figure 13 and Figure 14. This leads to maximum allowable values of resultant horizontal load and moment of $\mathrm{H}_{\max }=372 \mathrm{kN}$ and $\mathrm{M}_{\max }=2373 \mathrm{kNm}$ for this example. The resulting H-M failure envelope expressed by Equations (18) and (19) is then as shown by the outer envelope in Figure 23a, together with the design loading.

Step 5: Reduced ultimate horizontal and moment capacities due to normalised torsion loading are evaluated through Equations (14) and (17), and Figure 16 and Figure 17. The effect of the applied torsion in this example is to further reduce $\mathrm{H}_{\max }$ and $\mathrm{M}_{\max }$ to $312 \mathrm{kN}$ and $2282 \mathrm{kNm}$ respectively, as indicated by the inner failure envelope in Figure 23a.

Step 6: The extent to which the applied (design) loading falls within H-M failure envelope, and thus the safety factor on material strength $\mathrm{su}_{\mathrm{u}}$, is then evaluated. For this example, the factored resultant horizontal load $(156 \mathrm{kN})$ is about $50 \%$ of the maximum allowable value. However, the reserve strength ratio is much less than 2 since as the material factor on soil shear strength is increased, the mobilisation ratios for vertical and torsional loading increase, resulting in disproportionate decreases in $\mathrm{H}_{\max }$ and $\mathrm{M}_{\max }$. This is illustrated in Figure 23b, which shows conditions corresponding to the 'failure' material factor, which turns out to be 1.53. $\mathrm{H}_{\max }$ and $\mathrm{M}_{\max }$ are now respectively $157 \mathrm{kN}$ and $1301 \mathrm{kNm}$. 


\section{CONCLUSIONS}

The overall aim of the work presented in this paper was to investigate the response of shallowly embedded rectangular mudmats to fully three-dimensional, six degree-of-freedom, loading conditions, $\mathrm{V}-\mathrm{H}^{2}-\mathrm{M}^{2}-\mathrm{T}$. The specific application for the work is the type of foundation used in deep water by the offshore oil and gas industry for pipeline terminations and well manifolds. Finite element analyses considered a rectangular mudmat with aspect ratio $\mathrm{B} / \mathrm{L}$ of 0.5 and embedment ratios $\mathrm{d} / \mathrm{B}$ up to 0.2 in soil with linearly increasing shear strength with depth, $0 \leq \kappa=\mathrm{kB} / \mathrm{s}_{\mathrm{u} 0} \leq 10$.

A design methodology is proposed whereby the six degree-of-freedom $\mathrm{V}-\mathrm{H}^{2}-\mathrm{M}^{2}-\mathrm{T}$ interaction is reduced to a two dimensional failure envelope in resultant H-M space, adjusted for the effects of vertical and torsional loading. Algebraic expressions are proposed for prediction of uniaxial and combined loading capacities. The expressions presented in the paper are accurate for interpolating mudmat capacity within the range of conditions considered in this study. The methodology is considered applicable for a wider range of conditions but the coefficients of the fitting expressions, and in some cases the fitting expressions themselves, may need redefining for foundation aspect ratios, B/L, much less than the value of 0.5 considered, or for embedment ratios significantly greater than 0.2 .

An example application was presented, illustrating how the methodology may be applied to evaluate the reserve strength capacity for a given mudmat geometry and factored loads. In principle, the approach allows the mudmat size to be optimised for given required loading conditions, soil shear strength profile, and design load and material factors.

\section{ACKNOWLEDGEMENTS}

The research presented here derives from a research collaboration between the Centre for Offshore foundation Systems( COFS) and Subsea 7. Subsea 7 is the owner of the intellectual property resulting from the collaboration and some features contained in this work are covered by pending patent. The Centre for Offshore Foundation Systems (COFS) is currently supported as a node of the Australian Research Council Centre of Excellence for Geotechnical Science and Engineering and in partnership with The Lloyd's Register Foundation.

\section{NOTATION}




\begin{tabular}{|c|c|}
\hline$B$ & mudmat breath \\
\hline$d$ & mudmat embedment \\
\hline$H_{\mathrm{x}}, H_{\mathrm{y}}$ & horizontal load along $\mathrm{x}$ - and $\mathrm{y}$ - axis \\
\hline$H_{\text {xult }}, H_{\text {yult }}$ & ultimate Horizontal load along $\mathrm{x}$ - and $\mathrm{y}$-axis \\
\hline$h$ & normalised horizontal load $\left(H / H_{\text {ult }}\right)$ \\
\hline$k$ & shear strength gradient \\
\hline$L$ & mudmat length \\
\hline$M_{\mathrm{x}}, M_{\mathrm{y}}$ & moment along $\mathrm{x}$ - and $\mathrm{y}$-axis \\
\hline$M_{\text {xult }}, M_{\text {yult }}$ & ultimate moment about $\mathrm{x}$ - and $\mathrm{y}$-axis \\
\hline$m$ & normalised moment $\left(M / M_{\text {ult }}\right)$ \\
\hline$s_{\mathrm{um}}$ & undrained strength at mudline level \\
\hline$S_{\mathrm{u} 0}$ & undrained strength at level of skirt tip \\
\hline$S_{\mathrm{u}}$ & undrained shear strength \\
\hline$T$ & torsion \\
\hline$T_{\text {ult }}$ & ultimate torsional capacity \\
\hline$t$ & normalised torsion $\left(T / T_{\text {ult }}\right)$ \\
\hline$V$ & vertical load \\
\hline$V_{u l t}$ & ultimate vertical load \\
\hline$v$ & normalised vertical load ( $\left.V / V_{\text {ult }}\right)$ \\
\hline$\alpha_{\text {skirt }}$ & friction ratio of skirts \\
\hline$\gamma^{\prime}$ & effective unit weight \\
\hline$\theta$ & direction of resultant horizontal load \\
\hline$\theta_{\mathrm{m}}$ & direction of resultant moment \\
\hline$\kappa$ & soil heterogeneity factor $\left(k B / s_{\mathrm{u} 0}\right)$ \\
\hline
\end{tabular}

\section{REFERENCES}

API (2011) Recommended Practice 2GEO Geotechnical and Foundation Design Considerations, $1^{\text {st }}$ Edition, American Petroleum Institute, Washington.

Bienen B, Byrne BW, Houlsby GT and Cassidy MJ (2006) Investigating six-degree-offreedom loading of shallow foundations on sand. Géotechnique 56(6): 367-379.

Bransby, MF and Randolph, MF (1998) Combined loading of skirted foundations. Géotechnique 48(5):637-655.

Bransby, MF and Randolph, MF (1999) The effect of embedment depth on the undrained response of skirted foundations to combined loading. Soils and Foundations 39(4):19-33.

Bransby, MF and Yun, G (2009) The undrained capacity of skirted strip foundations under combined loading. Géotechnique 59(2):115-125. 
Brinch, Hansen, J (1970) A revised and extended formula for bearing capacity. Danish Geotech. Inst. Bull., No. 28:5-11.

Butterfield, R, Houlsby, GT and Gottardi, G (1997) Standardized sign conventions and notation for generally loaded foundations. Géotechnique 47(5): 1051-1054.

Dassault Systèmes (2010) Abaqus analysis users' manual. Simula Corp, Providence, RI, USA.

Davis, EH and Booker, JR (1973) The effect of increasing strength with depth on the bearing capacity of clays. Géotechnique 23(4), 551-563.

Dimmock, P, Clukey, EC, Randolph, MF, Gaudin, C. and Murff, JD (2013) Hybrid subsea foundations for subsea equipment. J. of Geotechnical and Geoenvironmental Engineering ( under review).

Finnie, IMS and Morgan, N (2004) Torsional loading of subsea structures. In Proc. $4^{\text {th }}$ Int. Offshore and Polar Engng Conf., Toulon, France, pp. 326-333.

Gaudin, C, Randolph, MF, Feng, X, Clukey, EC and Dimmock, P (2012) Centrifuge modelling of a hybrid foundation for subsea equipment. In Proc. $7^{\text {th }}$ Int. Conf. Offshore Site Investigation and Geotechnics, Society for Underwater Technology, London, UK, pp. 411-420.

Gourvenec, S and Barnett, S (2011) Undrained failure envelope for skirted foundations under general loading. Géotechnique, 61(3): 263 - 270.

Gourvenec, S (2008) Undrained bearing capacity of embedded footings under general loading. Géotechnique, 58(3): 177-185.

Gourvenec, S (2007) Shape effects on the capacity of rectangular footings under general loading. Géotechnique 57(8): 637-646.

Gourvenec, S, Randolph, M and Kingsnorth, O (2006) Undrained bearing capacity of square and rectangular footings. International Journal of Geomechanics 6(3): 147-157.

Gourvenec, S and Randolph, MF (2003) Effect of strength non-homogeneity on the shape and failure envelopes for combined loading of strip and circular foundations on clay. Géotechnique 53(6): 575-586.

Green, AP (1954) The plastic yielding of metal junctions due to combined shear and pressure. J Mech. Phys. Solids 2(3):197-211.

Houlsby, GT and Wroth, CP (1983) Calculation of stresses on shallow penetrometers and footings. In Proc. IUTAM/IUGG, Seabed Mechanics, pp. 107-112.

Houlsby, GT and Purzin, AM (1999) The bearing capacity of a strip footing on clay under combined loading. In Proc. R. Soc. London, Ser.A, 455(1983), pp. 893-916.

ISO 19901-4 (2003) Petroleum and natural gas industries - specific requirements for offshore structures - Part 4: Geotechnical and foundation design considerations, 1st Edition. International Standardisation Organisation.

Meyerhof, GG (1953) The bearing capacity of foundations under eccentric and inclined loads. In Proc. $3^{\text {rd }}$ Int. Conf. Soil Mech. Found. Engng, Zurich, Switzerland, vol.1, pp. 440-445.

Murff, JD, Aubeny, CP and Yang, M (2010) The effect of torsion on the sliding resistance of rectangular foundations. In Proc, $2^{\text {nd }}$ Int. Symp. Frontiers in Offshore Geotechnics, Perth, Australia, pp. 439-443. 
Prandtl, L (1921) "Eindringungsfestigkeit und festigkeit von schneiden". Angew. Math. U. Mech, 1(1): 15-20.

Randolph, MF and Puzrin, AM (2003) Upper bound limit analysis of circular foundations on clay under general loading. Géotechnique 53(9): 785-796.

Randolph, MF (2012) Offshore geotechnics - the challenges of deepwater soft sediments. In Proc. GeoCongress 2012, State of the Art and Practice in Geotechnical Engineering, Oakland, Ca, ASCE Geotechnical Special Publication No. 226, pp. 241-271.

Salgado, R, Lyamin, AV, Sloan, SW and Yu, HS (2004) Two- and three-dimensional bearing capacity of foundations in clay. Géotechnique 54(5): 297-306.

Taiebat, HA and Carter, JP (2000) Numerical studies of the bearing capacity of shallow foundations on cohesive soil subjected to combined loading. Géotechnique 50(4): 409418.

Taiebat, HA and Carter, JP (2002) Bearing capacity of strip and circular foundations on undrained clay subjected to eccentric loads. Géotechnique 52(1): 61-64.

Taiebat, HA and Carter, JP (2010) A failure surface for circular footings on cohesive soils. Géotechnique 60(4): 265-273.

Tan, FS (1990) Centrifuge and theoretical modelling of conical footings on sand. PhD thesis, Cambridge University, UK.

Yun, G and Bransby, MF (2007) The horizontal-moment capacity of embedded foundations in undrained soil. Can.Geotech. J. 44: 409-424.

Yun, G, Maconochie, A, Oliphant, J and Bransby, MF (2009) Undrained capacity of surface footings subjected to combined V-H-T loading. In Proc. $9^{\text {th }}$ Int. Offshore and Polar Engineering Conference, Osaka, Japan, pp. 9-14. 
Table 1 Design steps for mat foundation

\begin{tabular}{|c|l|}
\hline Step & \multicolumn{1}{|c|}{ Details } \\
\hline 1 & $\begin{array}{l}\text { For given foundation geometry evaluate } \mathrm{s}_{\mathrm{u} 0} \text { and non-dimensional quantities B/L, } \\
\text { d/B and } \kappa\end{array}$ \\
\hline 2 & $\begin{array}{l}\text { Evaluate uniaxial capacities for vertical, horizontal, moment and torsional } \\
\text { loading }\end{array}$ \\
\hline 3 & $\begin{array}{l}\text { Reduce ultimate horizontal, moment and torsional capacities to maximum values } \\
\text { available, according to mobilised (design) vertical capacity, } \mathrm{v}=\mathrm{V} / \mathrm{V}_{\mathrm{ult}}\end{array}$ \\
\hline 4 & $\begin{array}{l}\text { For given angle of resultant horizontal load, evaluate corresponding ultimate } \\
\text { horizontal capacity, and similarly for ultimate moment capacity }\end{array}$ \\
\hline 5 & $\begin{array}{l}\text { Evaluate reduced ultimate horizontal and moment capacities due to normalised } \\
\text { torsional loading }\end{array}$ \\
\hline 6 & $\begin{array}{l}\text { Evaluate extent to which applied (design) loading falls within } \mathrm{H}-\mathrm{M} \text { failure } \\
\text { envelope, and thus safety factors on self-weight V, live loading H, M, T or } \\
\text { material strength } \mathrm{s} 0\end{array}$ \\
\hline
\end{tabular}

Table 2 Input data for example mudmat design

\begin{tabular}{|l|c|l|l|c|l|}
\hline \multicolumn{1}{|c|}{ Parameter } & Value & Units & \multicolumn{1}{|c|}{ Parameter } & Value & Units \\
\hline Width, $\mathrm{B}$ & 6 & $\mathrm{~m}$ & Vertical load, $\mathrm{V}$ & 700 & $\mathrm{kN}$ \\
\hline Length, $\mathrm{L}$ & 12 & $\mathrm{~m}$ & Horizontal load, $\mathrm{H}_{\mathrm{x}}$ & 100 & $\mathrm{kN}$ \\
\hline Skirt, $\mathrm{d}$ & 0.5 & $\mathrm{~m}$ & Horizontal load, $\mathrm{H}_{\mathrm{y}}$ & 120 & $\mathrm{kN}$ \\
\hline Mudline strength, $\mathrm{sum}$ & 3.4 & $\mathrm{kPa}$ & Moment, $\mathrm{M}_{\mathrm{x}}$ & 200 & $\mathrm{kNm}$ \\
\hline Strength gradient, $\mathrm{k}$ & 1.5 & $\mathrm{kPa} / \mathrm{m}$ & Moment, $\mathrm{M}_{\mathrm{y}}$ & -360 & $\mathrm{kNm}$ \\
\hline Skirt friction ratio, $\alpha$ & 0.5 & & Torsion, $\mathrm{T}$ & 640 & $\mathrm{kNm}$ \\
\hline Soil unit weight, $\gamma^{\prime}$ & 6 & $\mathrm{kN} / \mathrm{m}^{3}$ & & & \\
\hline
\end{tabular}

Table 3 Uniaxial capacities for example mudmat design

\begin{tabular}{|l|c|l|c|c|}
\hline \multicolumn{1}{|c|}{ Parameter } & Value & Units & \multicolumn{2}{c|}{ Mobilisation ratios } \\
\hline Vertical, $\mathrm{V}_{\text {ult }}$ & 2561 & $\mathrm{kN}$ & $\mathrm{V} / \mathrm{V}_{\text {ult }}$ & 0.273 \\
\hline Horizontal, $\mathrm{H}_{\text {xult }}$ & 369 & $\mathrm{kN}$ & $\mathrm{H}_{\mathrm{x}} / \mathrm{H}_{\text {xult }}$ & 0.271 \\
\hline Horizontal, $\mathrm{H}_{\text {yult }}$ & 351 & $\mathrm{kN}$ & $\mathrm{H}_{\mathrm{y}} / \mathrm{H}_{\text {yult }}$ & 0.342 \\
\hline Moment, $\mathrm{M}_{\text {xult }}$ & 5845 & $\mathrm{kNm}$ & $\mathrm{M}_{\mathrm{x}} / \mathrm{M}_{\text {xult }}$ & 0.034 \\
\hline Moment, $\mathrm{M}_{\text {yult }}$ & 2149 & $\mathrm{kNm}$ & $\mathrm{M}_{\mathrm{y}} / \mathrm{M}_{\text {yult }}$ & 0.167 \\
\hline Torsion, $\mathrm{T}_{\text {ult }}$ & 1405 & $\mathrm{kNm}$ & $\mathrm{T} / \mathrm{T}_{\text {ult }}$ & 0.456 \\
\hline
\end{tabular}




\section{FIGURE CAPTIONS}

Figure 1 General loading for a rectangular mudmat and linearly varying soil strength

Figure 2 Resultant horizontal and moment loading

Figure 3 FE mesh for surface mudmat

Figure 4 Finite element results and fit for pure vertical bearing capacity factor

Figure 5 Finite element results and fit for pure horizontal capacity factor: (a) parallel to xaxis; (b) parallel to y-axis

Figure 6 Finite element results and fit for moment capacity factor: (a) about y-axis; (b) about $\mathrm{x}$-axis

Figure 7 Finite element results and fit for torsional capacity factor

Figure 8 Finite element results and fit for V-H failure envelopes: (a) V-H envelope in $\mathrm{x}-\mathrm{Z}$ plane (parallel to short edge); (b) V-H envelope in y-z plane (parallel to long edge)

Figure 9 Finite element results and fit for linearised V-M failure envelopes: (a) V-My plane (rotation about $\mathrm{y}$-axis); (b) $\mathrm{V}-\mathrm{M}_{\mathrm{x}}$ plane (rotation about $\mathrm{x}$-axis)

Figure 10 Finite element results and fit for V-T failure envelope

Figure 11 Normalised failure envelopes for biaxial horizontal loading of mudmats with varying embedment ratio

Figure 12 Failure envelopes for biaxial horizontal loading of a surface mudmat with varying vertical load

Figure 13 Effects of soil heterogeneity on combined $\mathrm{M}_{\mathrm{y}}-\mathrm{M}_{\mathrm{x}}$ failure envelopes

Figure 14 Effects of embedment ratio on combined $\mathrm{M}_{\mathrm{y}}-\mathrm{M}_{\mathrm{x}}$ failure envelopes

Figure 15 Normalised H-T failure envelopes for surface mudmat

Figure 16 Effects of soil heterogeneity and foundation embedment ratio on normalised H-T failure envelopes: (a) Combined $\mathrm{H}_{\mathrm{x}}$-T loading capacity; (b) Combined $\mathrm{H}_{\mathrm{y}}$-T loading capacity

Figure 17 Effect of soil heterogeneity and foundation embedment ratio on normalised M-T failure envelopes: (a) Resultant moment angle $\theta_{\mathrm{m}}=0^{\circ}$; (b) Resultant moment angle $\theta_{\mathrm{m}}=90^{\circ}$

Figure 18 Example showing effect of position of the LRP on normalised failure envelopes for $\mathrm{H}_{\mathrm{x}}-\mathrm{M}_{\mathrm{y}}$ loading: (a) LRP at $\mathrm{z}=0$; (b) LRP at $\mathrm{z}=\mathrm{d}$

Figure 19 Effects of soil heterogeneity on normalised $\mathrm{H}_{\mathrm{x}}-\mathrm{M}_{\mathrm{y}}$ failure envelopes for a surface mudmat

Figure 20 Effects of horizontal loading direction on combined H-M capacity for a surface mudmat on homogeneous soil

Figure 21 Effects of embedment ratio and soil heterogeneity on normalised H-M failure envelopes ( $L R P$ at $\mathrm{z}=\mathrm{d}$ ): (a) normalised $\mathrm{H}_{\mathrm{x}}-\mathrm{M}_{\mathrm{y}}$ failure envelopes; (b) normalised $\mathrm{H}_{\mathrm{y}}-\mathrm{M}_{\mathrm{x}}$ failure envelopes 
Figure 22 Normalised failure envelopes for H-M loading for varying torsion: (a) $\kappa=0, \theta=$ $30^{\circ}$; (b) $\kappa=0, \theta=60^{\circ}$; (c) $\kappa=5, \theta=0^{\circ}$; (d) $\kappa=10, \theta=90^{\circ}$

Figure 23 Failure envelopes and design loading for example application: (a) Unfactored shear strength data; (b) Factored shear strength data 


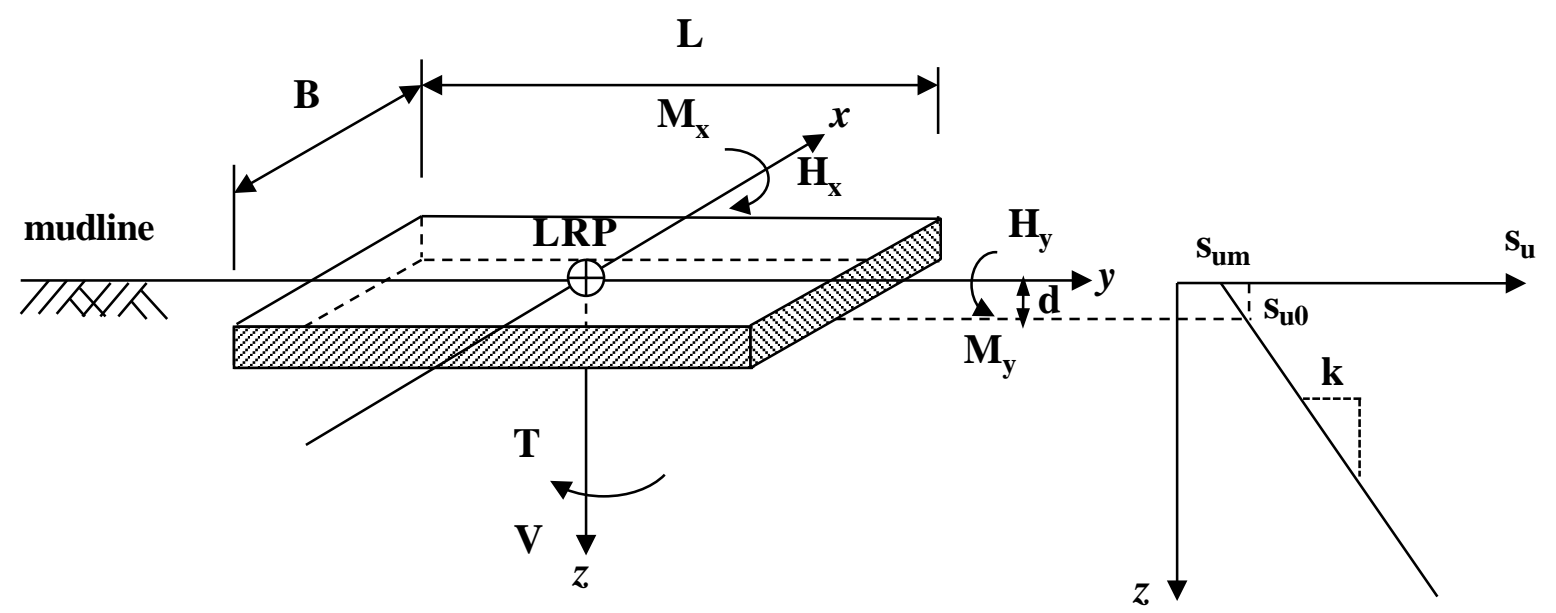

Figure 1 General loading for a rectangular mudmat and linearly varying soil strength

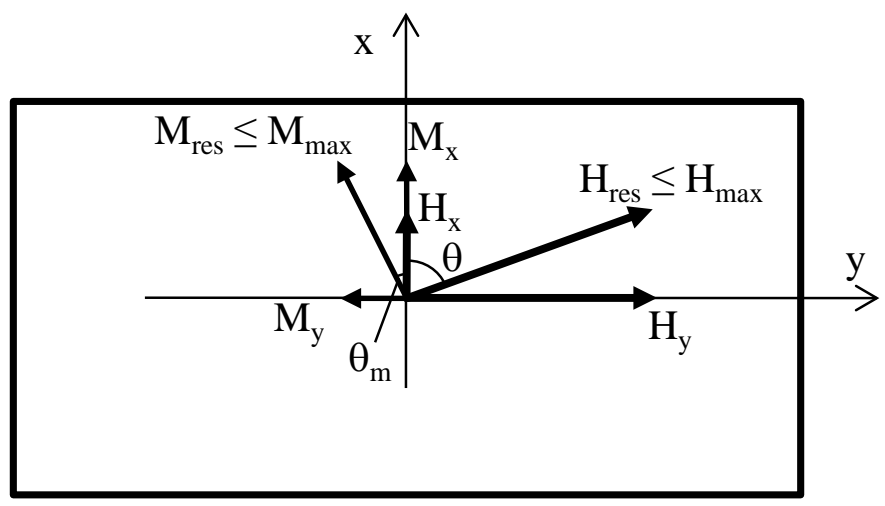

Figure 2 Resultant horizontal and moment loading 


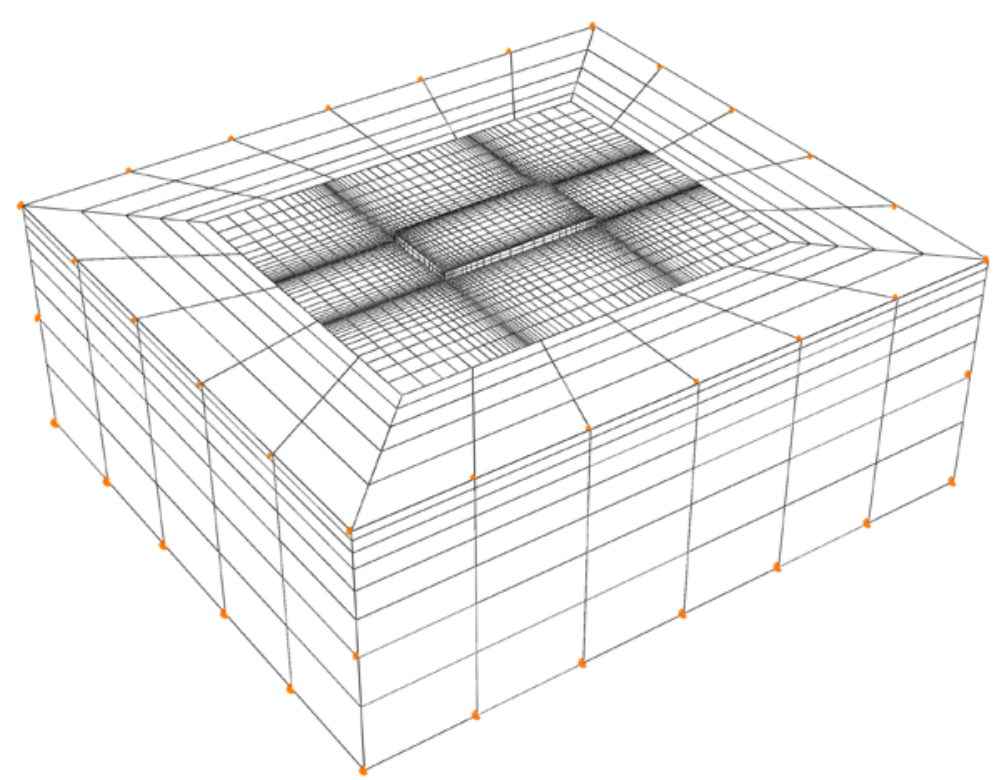

Figure 3 FE mesh for surface mudmat

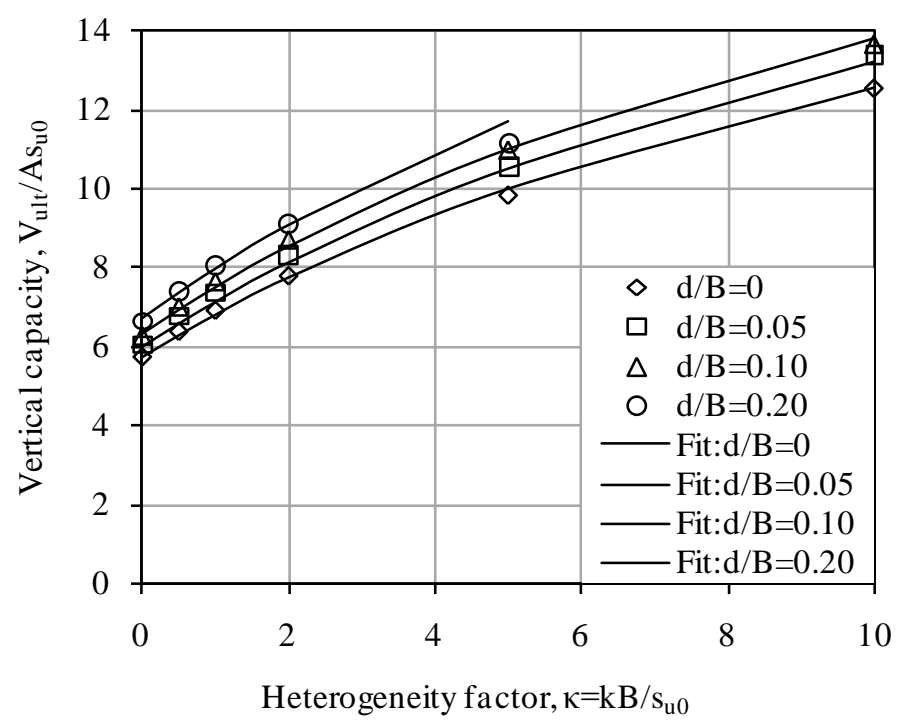

Figure 4 Finite element results and fit for pure vertical bearing capacity factor 


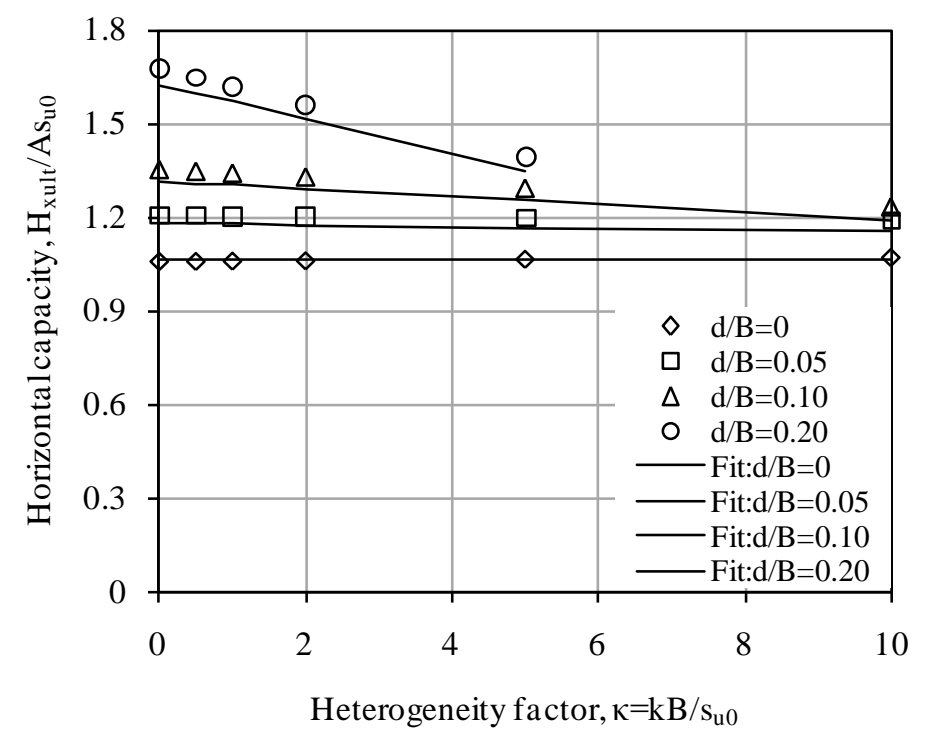

a) Parallel to X-axis: one-sided mechanism; smooth skirts

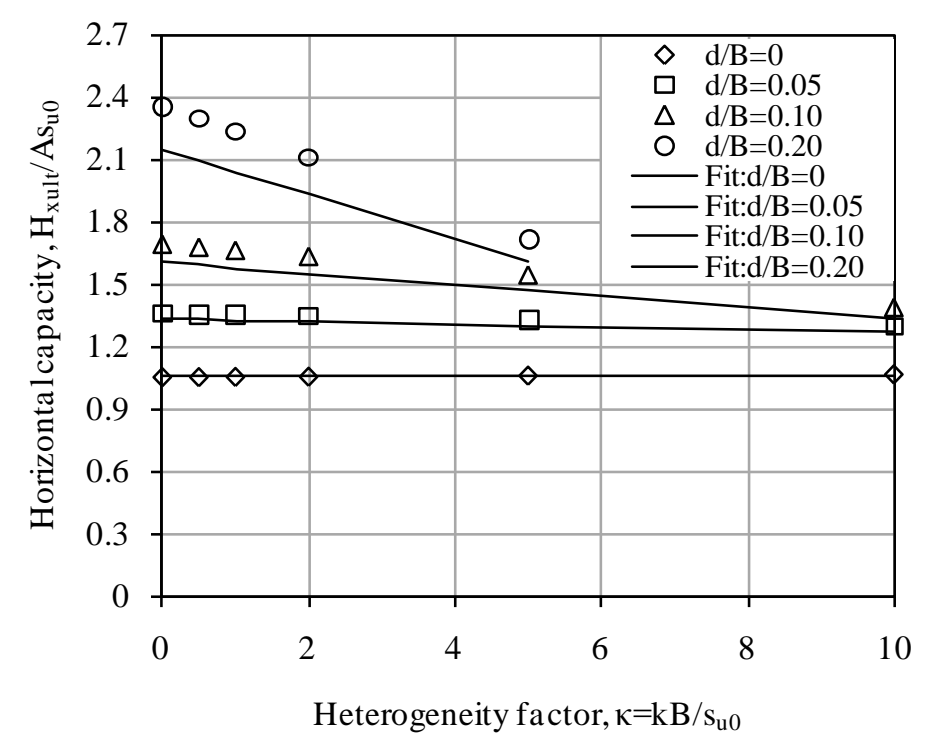

b) Parallel to x-axis: two-sided mechanism; rough skirts 


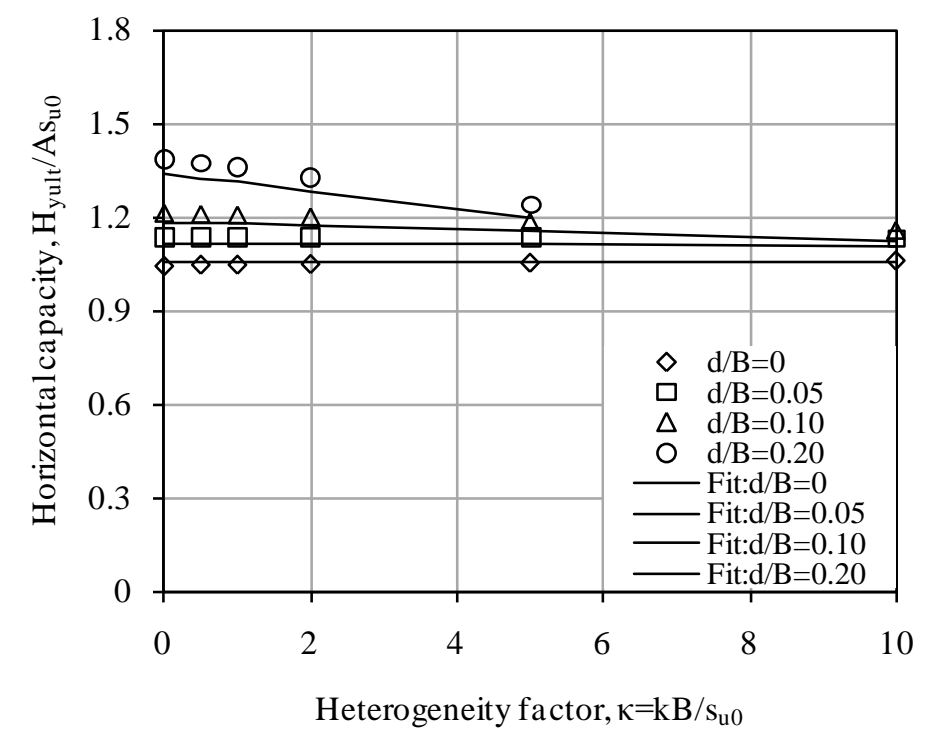

c) Parallel to y-axis: one-sided mechanism; smooth skirts

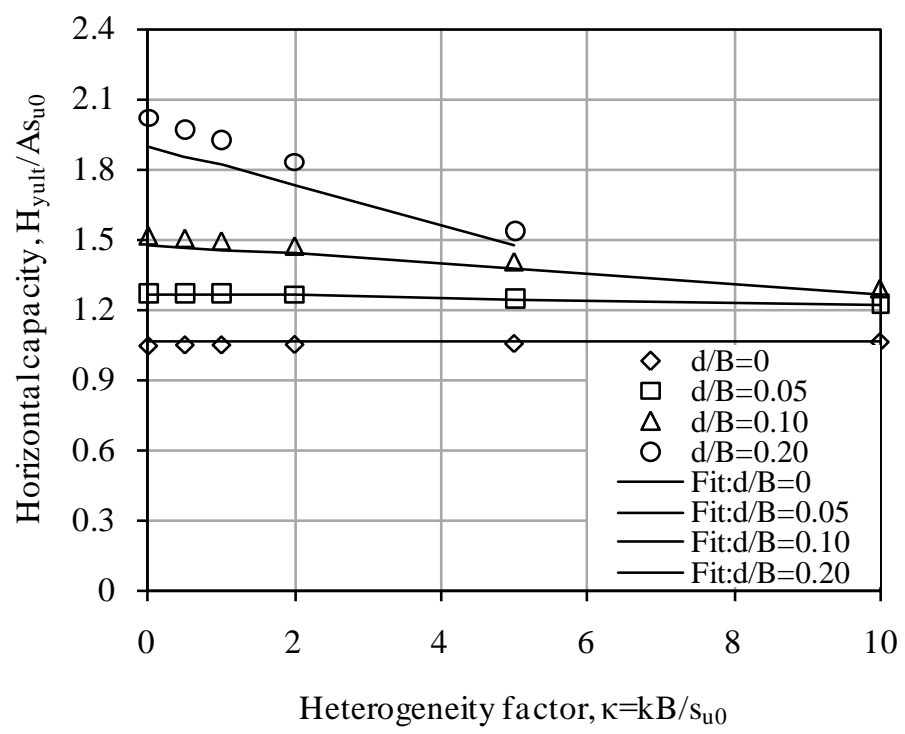

d) Parallel to y-axis: two-sided mechanism; rough skirts

Figure 5 Finite element results and fit for pure horizontal capacity factor 


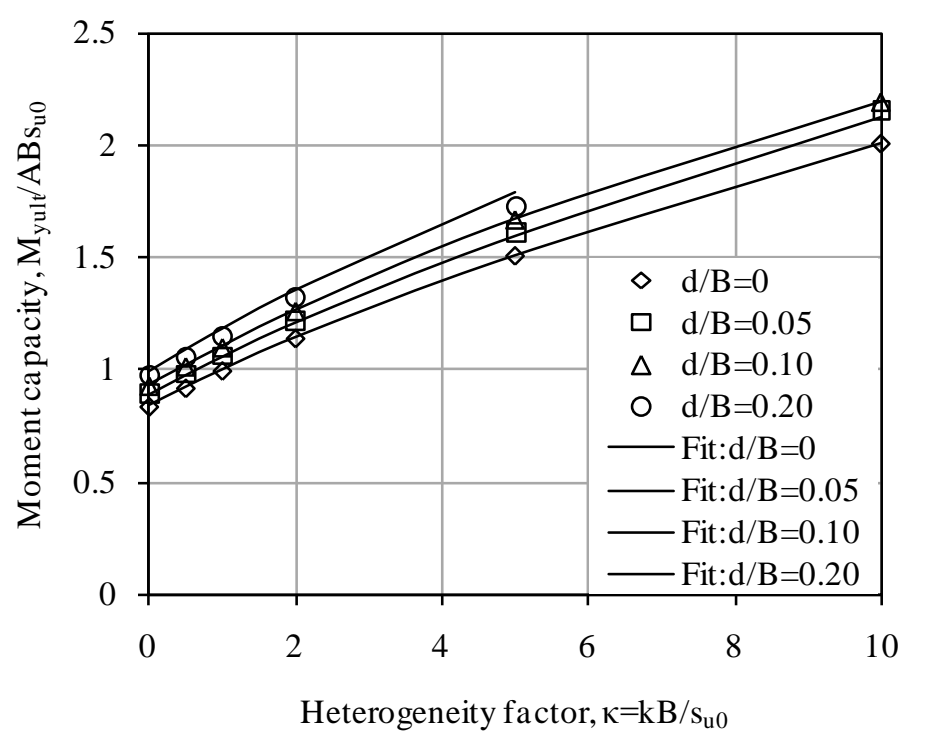

a) About y-axis

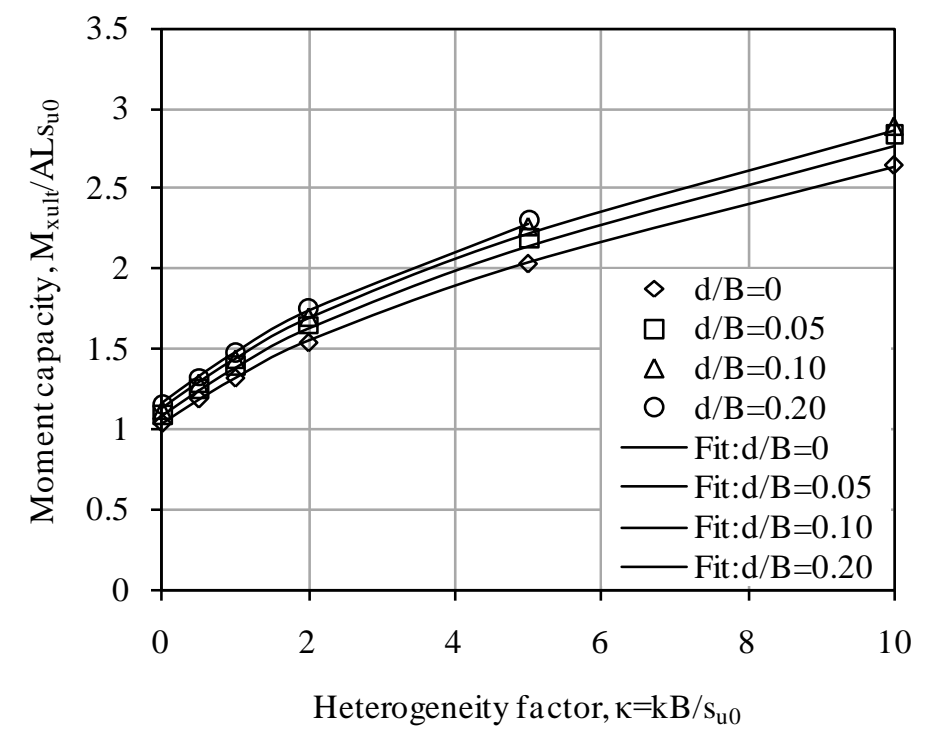

b) About $x$-axis

Figure 6 Finite element results and fit for moment capacity factor 


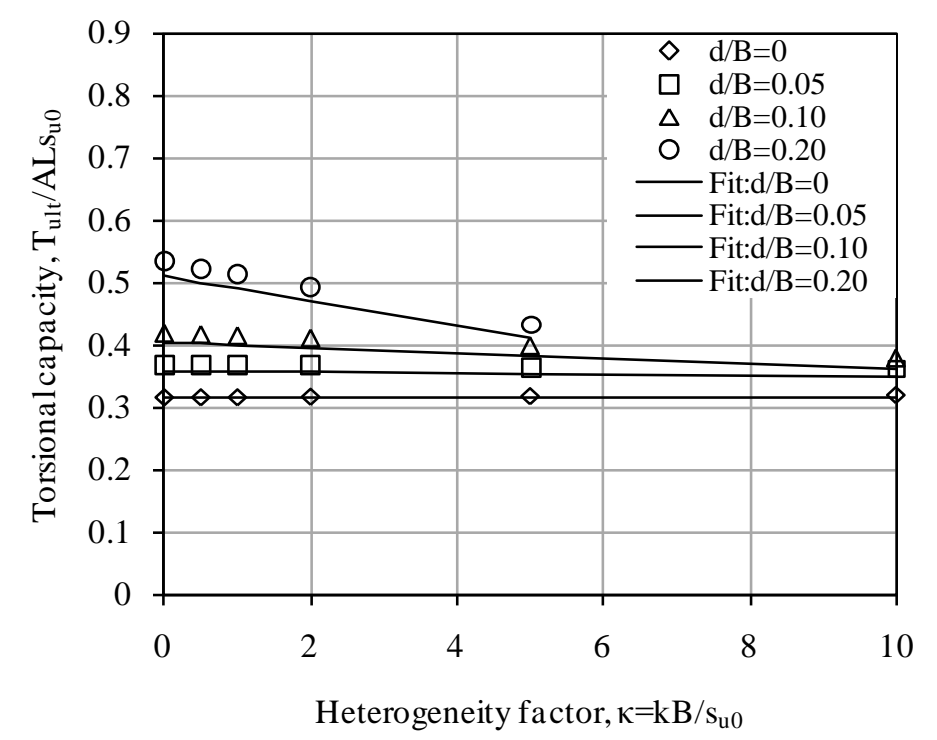

a) One-sided mechanism; smooth skirts

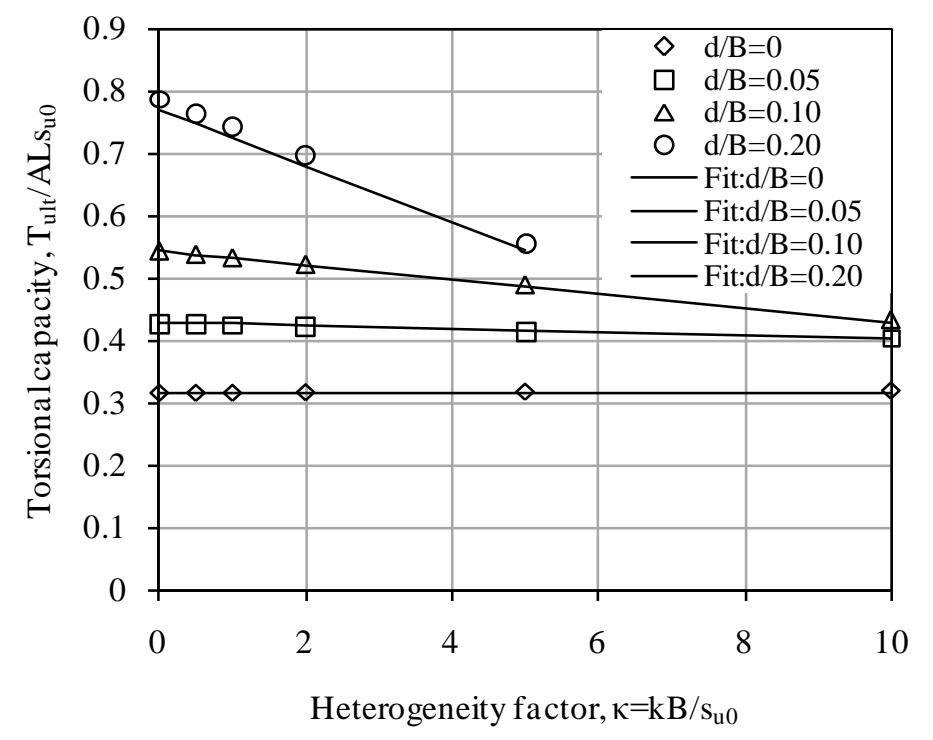

b) Two-sided mechanism; rough skirts

Figure 7 Finite element results and fit for torsional capacity factor 


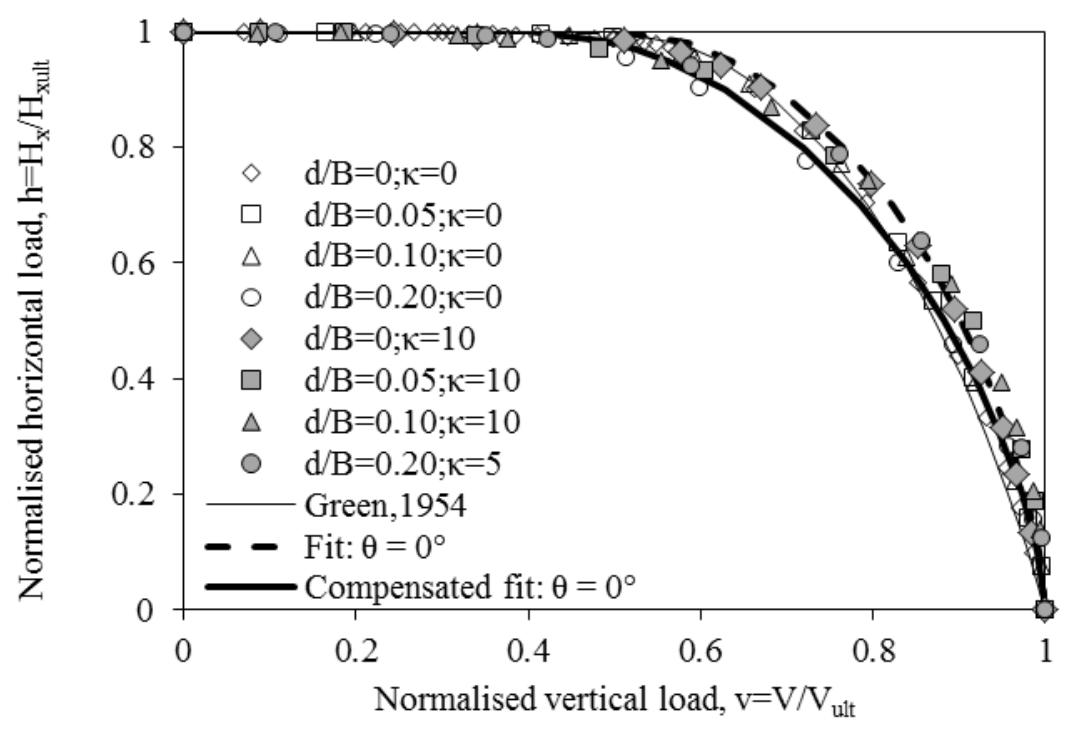

a) V-H envelope in $\mathrm{X}-\mathrm{z}$ plane (parallel to short edge)

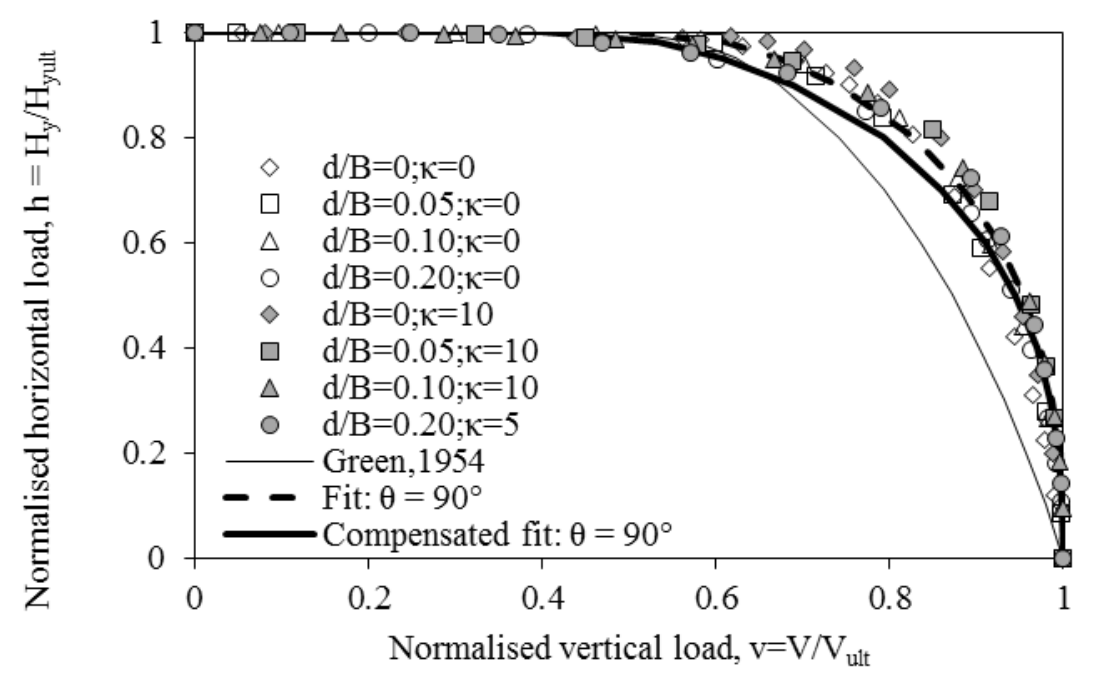

b) V-H envelope in y-z plane (parallel to long edge)

Figure 8 Finite element results and fit for V-H failure envelopes 


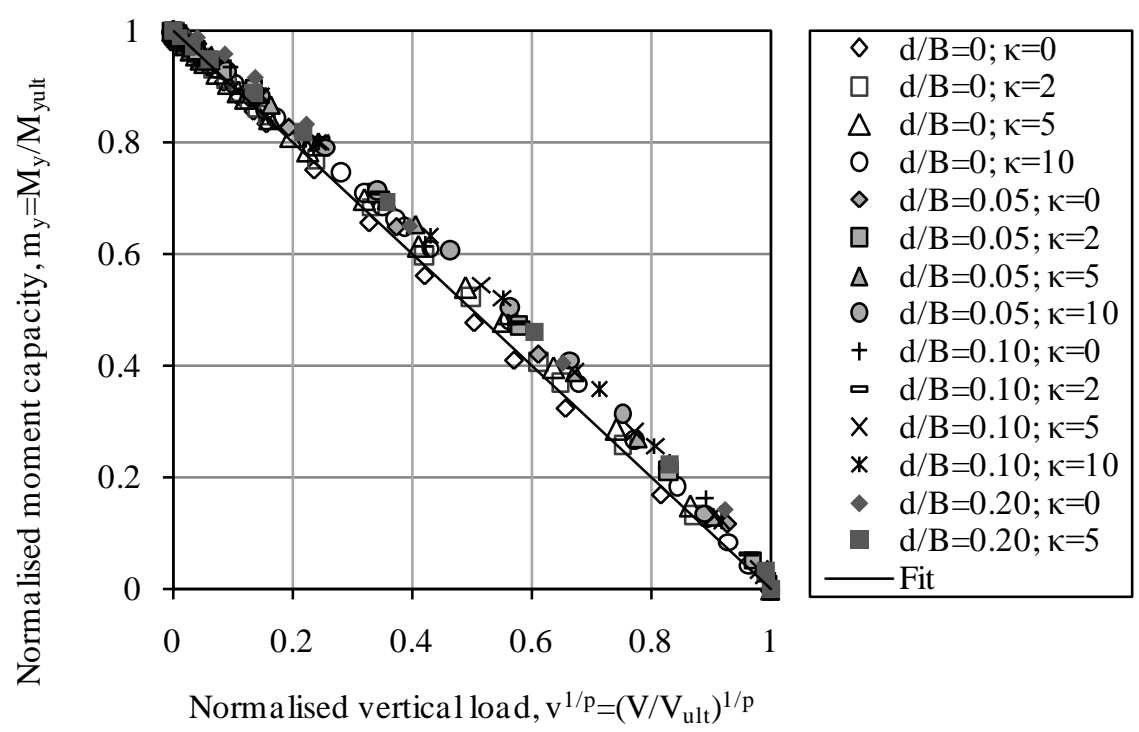

a) V-My plane (rotation about y-axis)

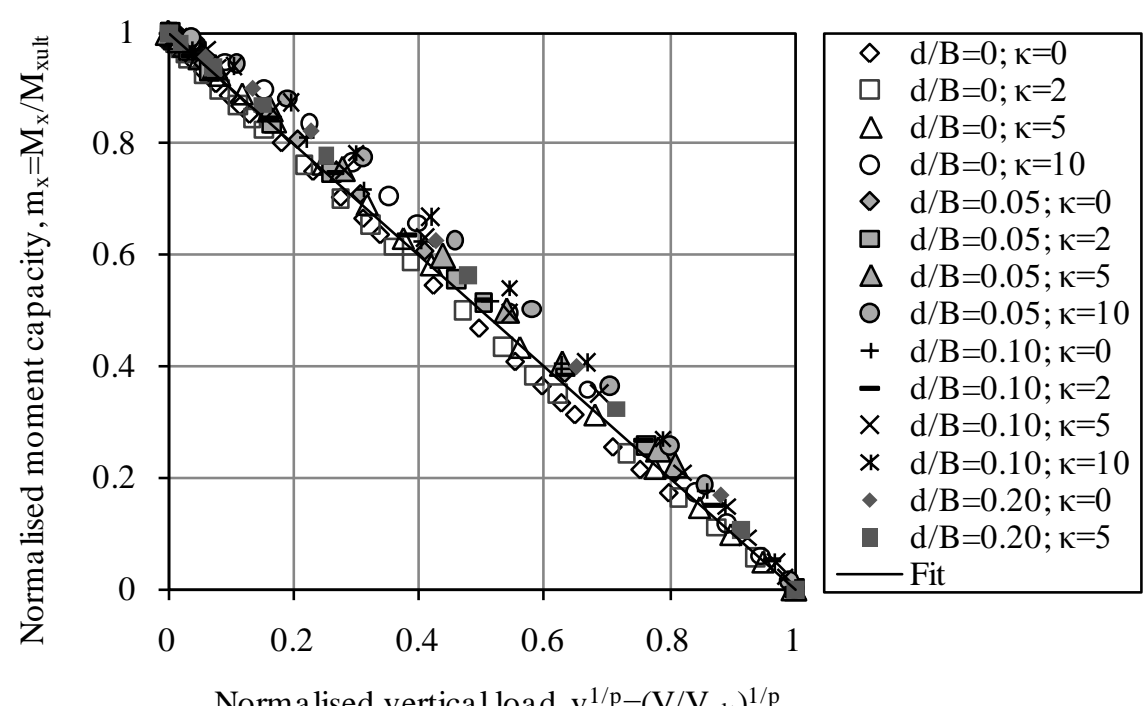

Norma lised vertical load, $\mathrm{v}^{1 / \mathrm{p}}=\left(\mathrm{V} / \mathrm{V}_{\mathrm{ult}}\right)^{1 / \mathrm{p}}$

b) $\mathrm{V}-\mathrm{M}_{\mathrm{x}}$ plane (rotation about $\mathrm{x}$-axis)

Figure 9 Finite element results and fit for linearised V-M failure envelopes 


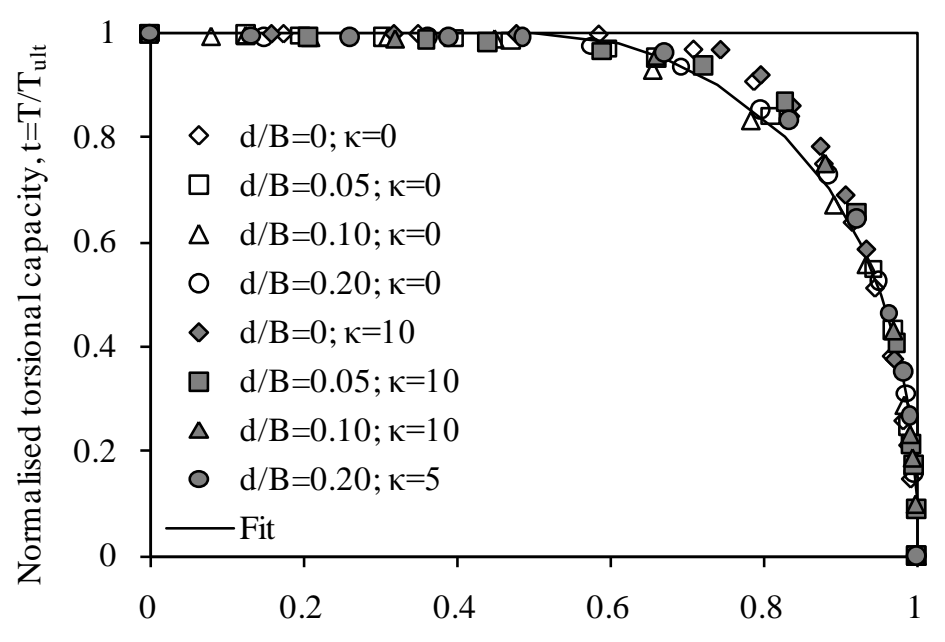

Normalised vertical capacity, $\mathrm{v}=\mathrm{V} / \mathrm{V}_{\mathrm{ult}}$

Figure 10 Finite element results and fit for V-T failure envelope

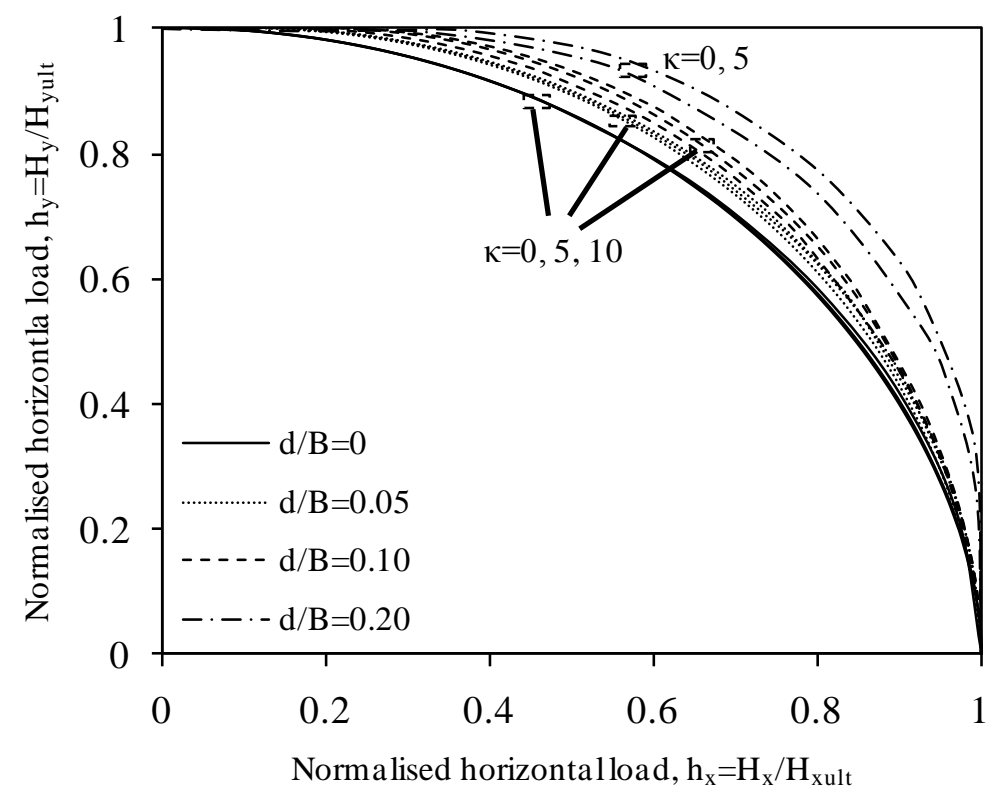

Figure 11 Normalised failure envelopes for biaxial horizontal loading of mudmats with varying embedment ratio 


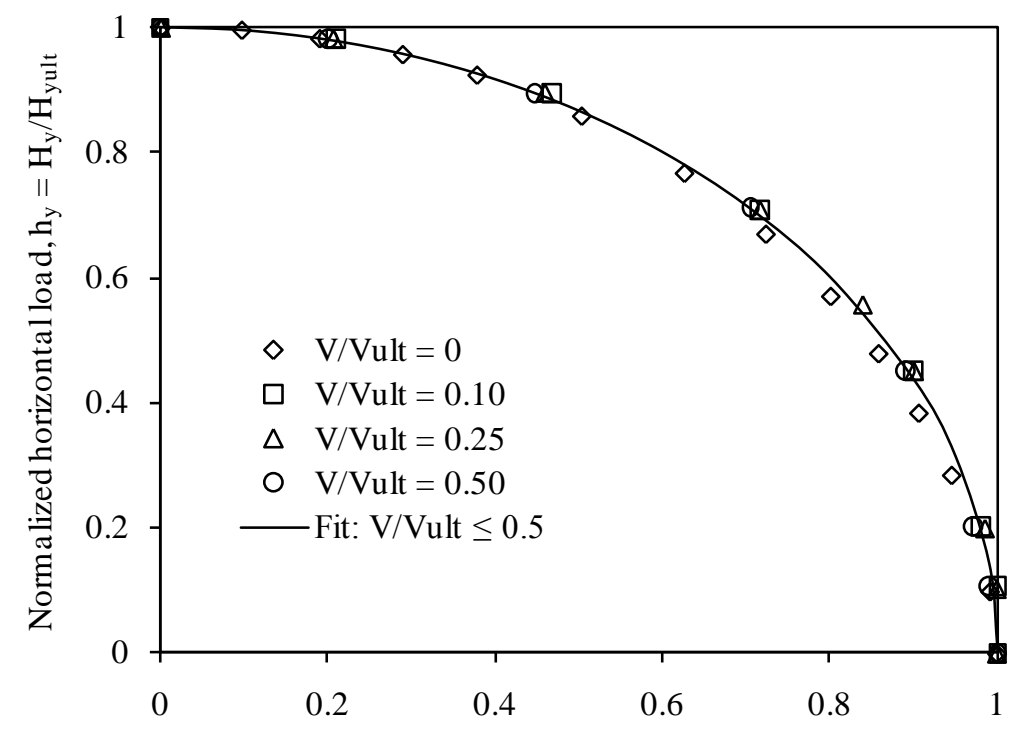

Normalized horizontal load, $\mathrm{h}_{\mathrm{x}}=\mathrm{H}_{\mathrm{x}} / \mathrm{H}_{\mathrm{xult}}$

Figure 12 Failure envelopes for biaxial horizontal loading of a surface mudmat with varying vertical load

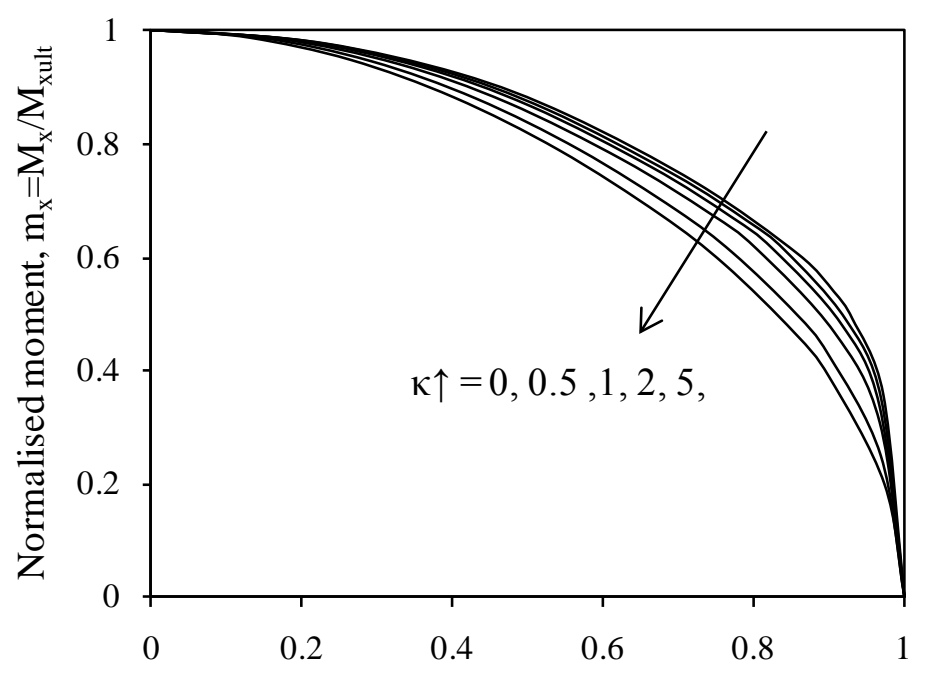

Normalised moment, $\mathrm{m}_{\mathrm{y}}=\mathrm{M}_{\mathrm{y}} / \mathrm{M}_{\mathrm{yult}}$

Figure 13 Effects of soil heterogeneity on combined $\mathrm{M}_{\mathrm{y}}-\mathrm{M}_{\mathrm{x}}$ failure envelopes 


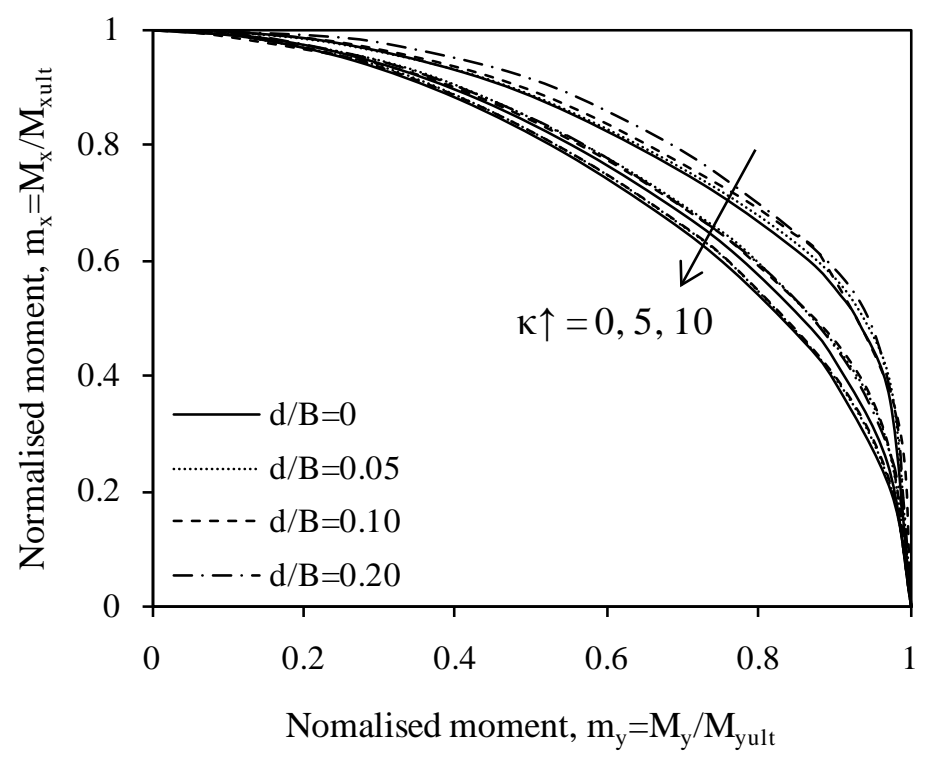

Figure 14 Effects of embedment ratio on combined $\mathrm{M}_{\mathrm{y}}-\mathrm{M}_{\mathrm{x}}$ failure envelopes

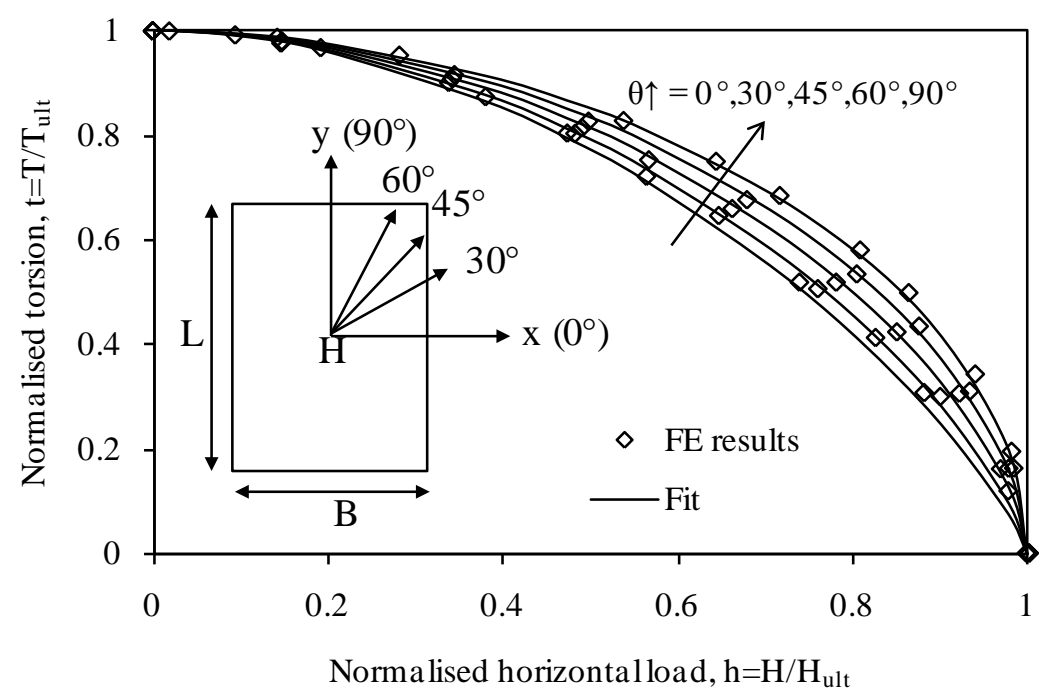

Figure 15 Normalised H-T failure envelopes for surface mudmat 


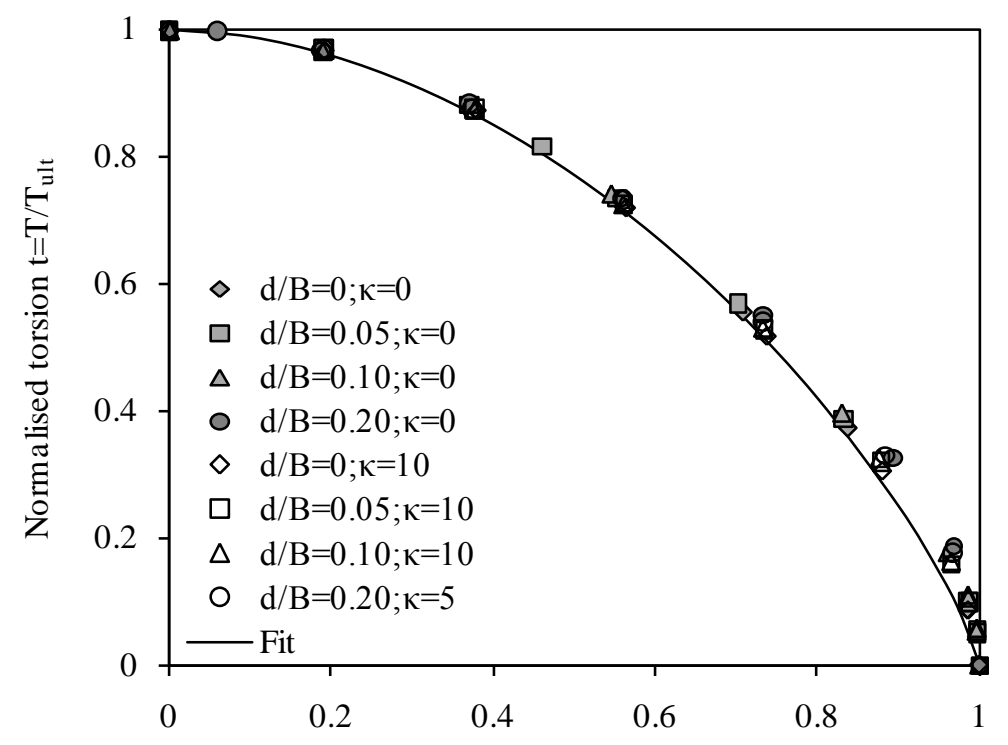

Normalised horizontal load, $\mathrm{h}=\mathrm{H} / \mathrm{H}_{\mathrm{ult}}\left(\theta=0^{\circ}\right)$

(a) Combined $\mathrm{H}_{\mathrm{x}}-\mathrm{T}$ loading capacity

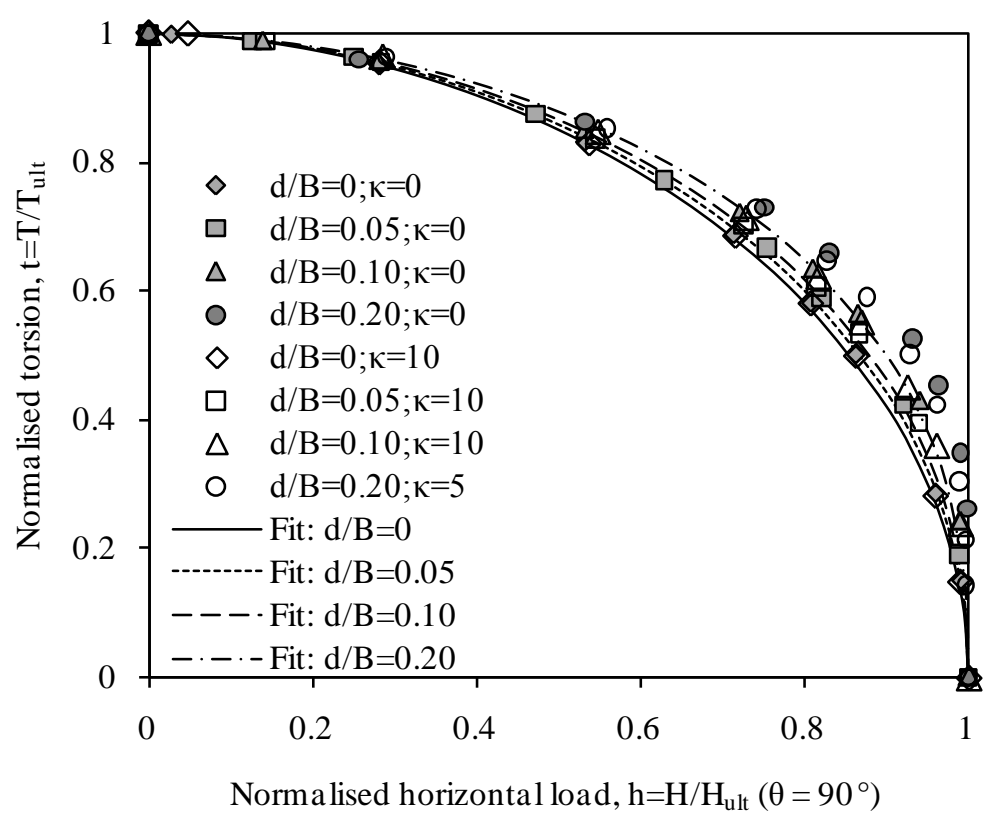

(b) Combined $\mathrm{H}_{\mathrm{y}}-\mathrm{T}$ loading capacity

Figure 16 Effects of soil heterogeneity and foundation embedment ratio on normalised H-T failure envelopes 


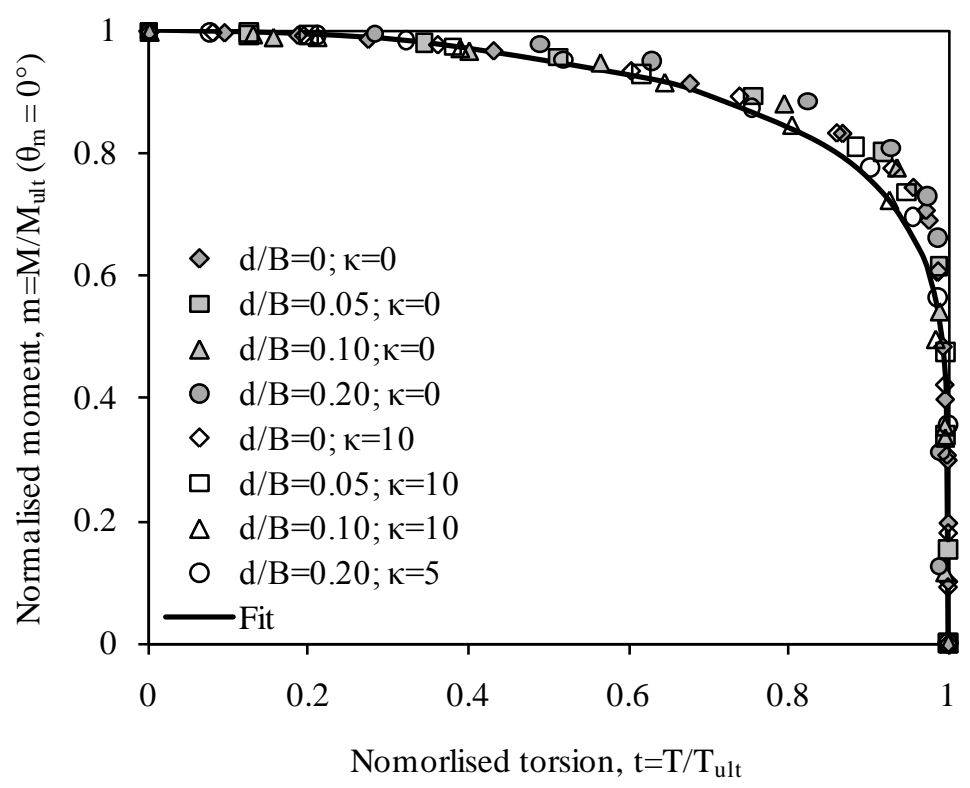

(a) Resultant moment angle $\theta_{\mathrm{m}}=0$

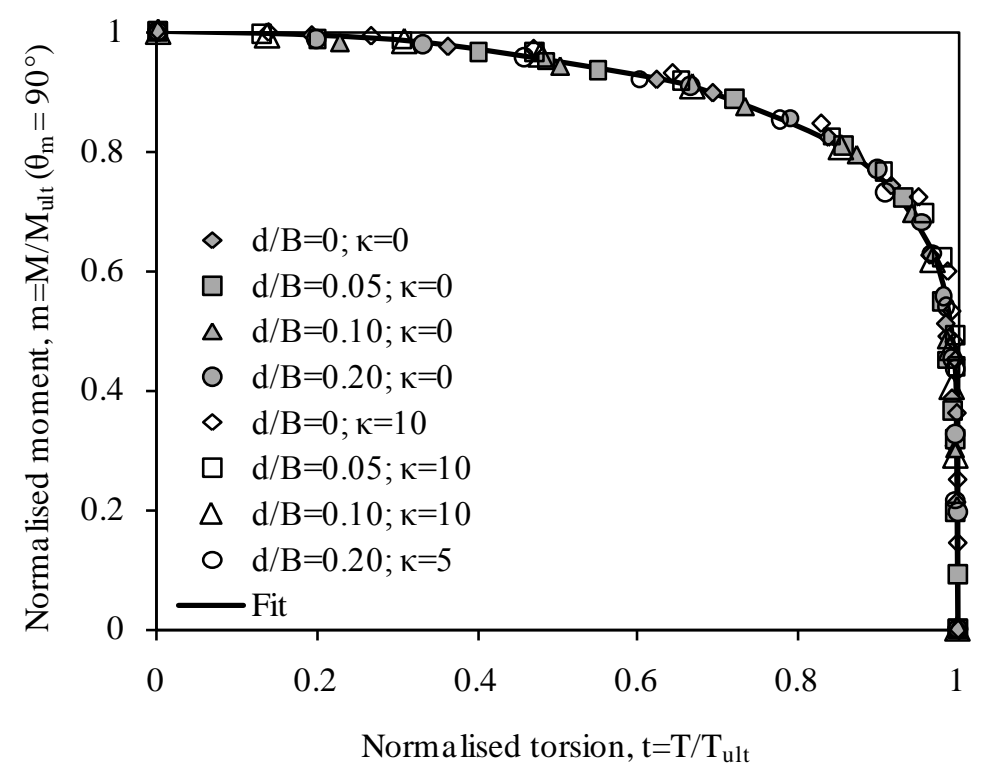

(a) Resultant moment angle $\theta_{\mathrm{m}}=90^{\circ}$

Figure 17 Effect of soil heterogeneity and foundation embedment ratio on normalised M-T failure envelopes 


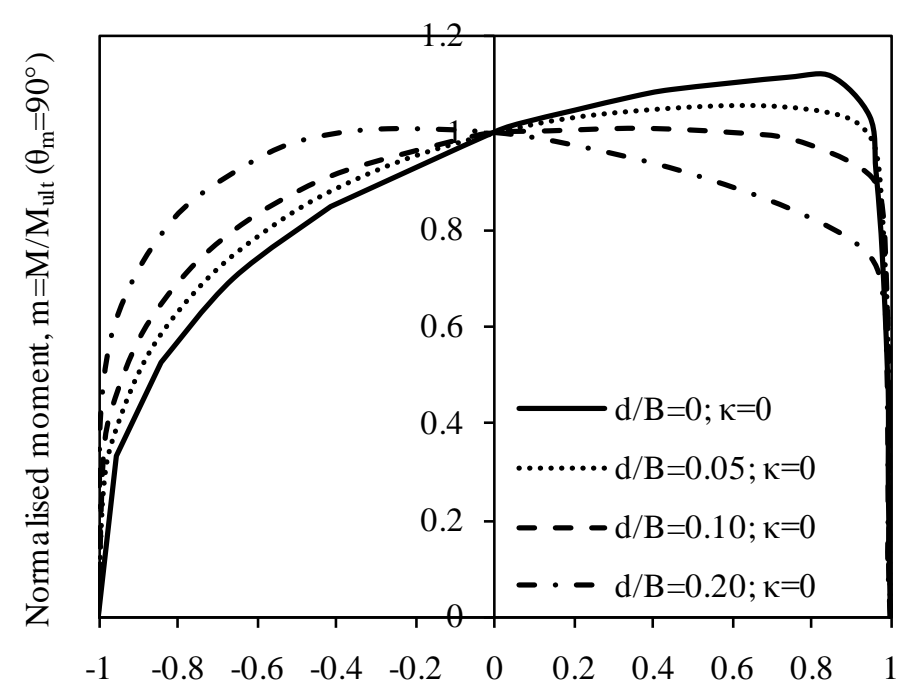

Norma lised horizontal load, $\mathrm{h}=\mathrm{H} / \mathrm{H}_{\mathrm{ult}}\left(\theta=0^{\circ}\right)$

(a) LRP at $\mathrm{z}=0$

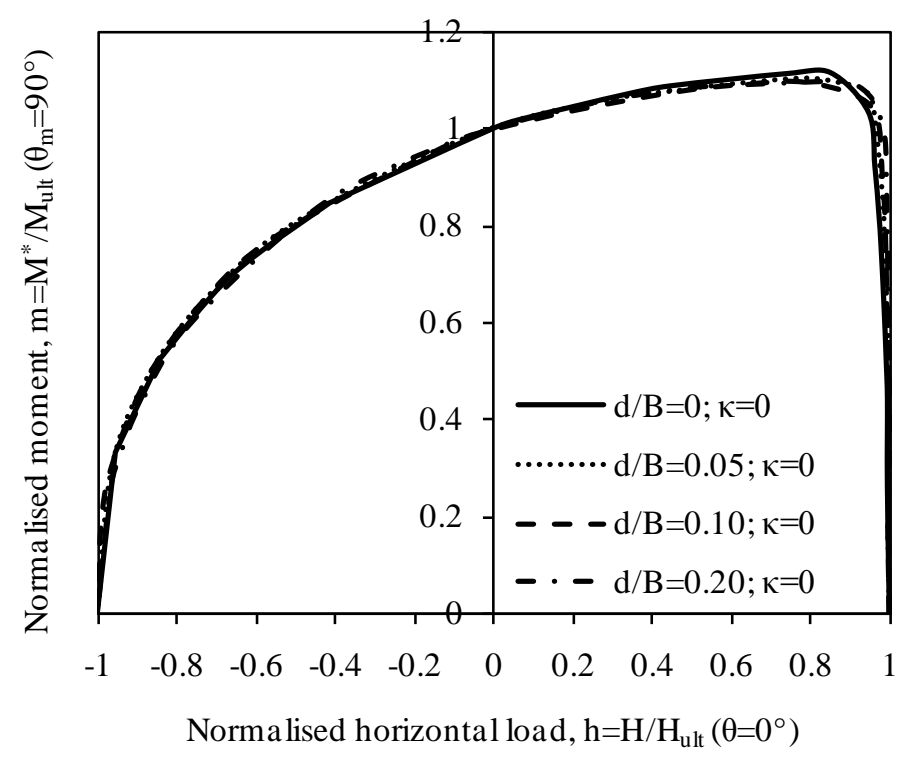

(b) LRP at $\mathrm{z}=\mathrm{d}$

Figure 18 Example showing effect of position of the LRP on normalised failure envelopes for $\mathrm{H}_{\mathrm{x}}-\mathrm{M}_{\mathrm{y}}$ loading 


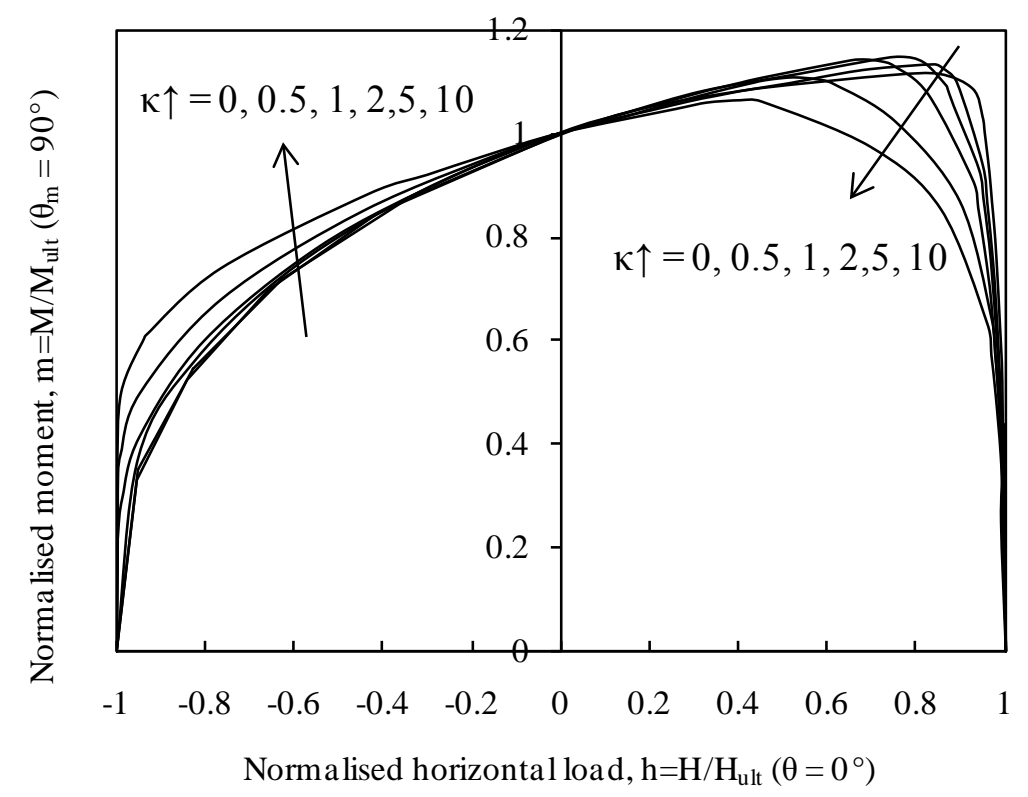

Figure 19 Effects of soil heterogeneity on normalised $\mathrm{H}_{\mathrm{x}}-\mathrm{M}_{\mathrm{y}}$ failure envelopes for a surface mudmat

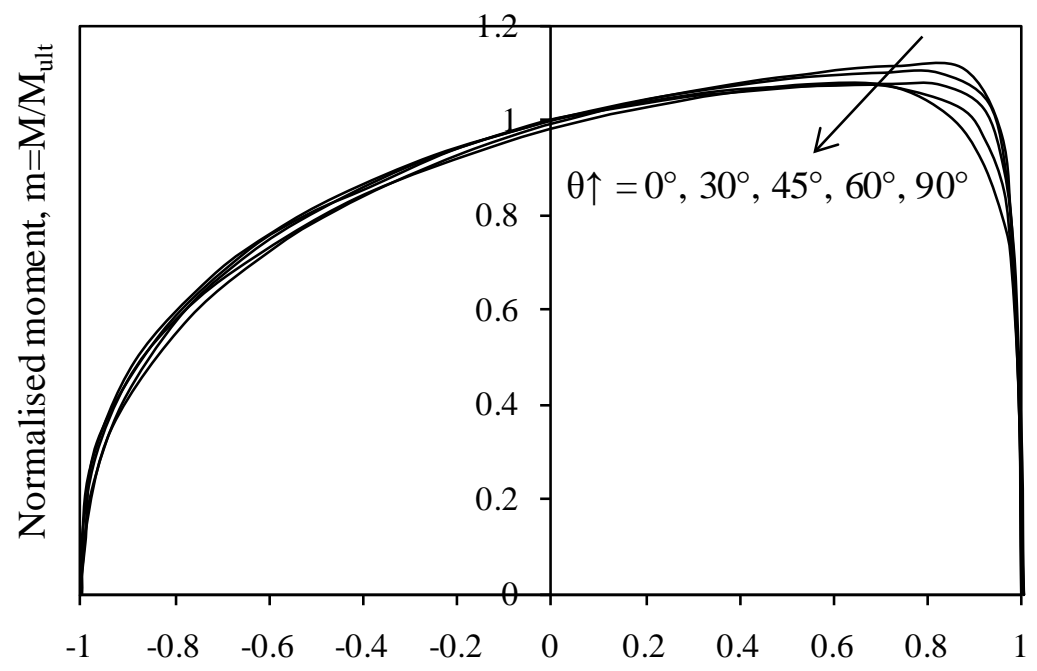

Normalised horizontal load, $\mathrm{h}=\mathrm{H} / \mathrm{H}_{\text {ult }}$

Figure 20 Effects of horizontal loading direction on combined H-M capacity for a surface mudmat on homogeneous soil 


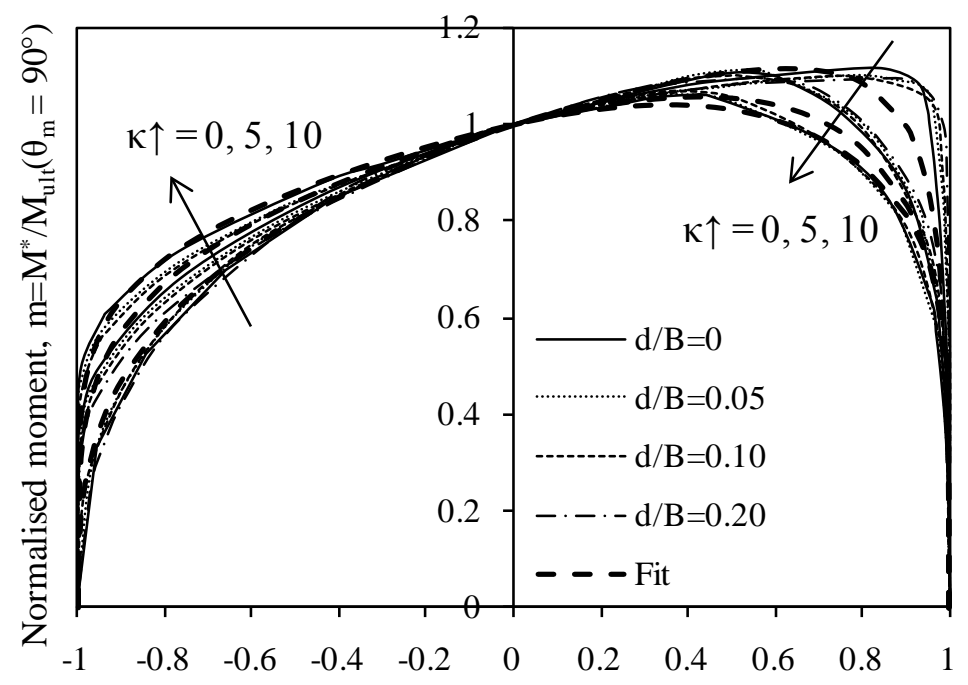

Normalised horizontal load, $\mathrm{h}=\mathrm{H} / \mathrm{H}_{\text {ult }}\left(\theta=0^{\circ}\right)$

a) Effects of embedment ratio and soil heterogeneity on normalised $H_{x}-M_{y}$ failure envelopes

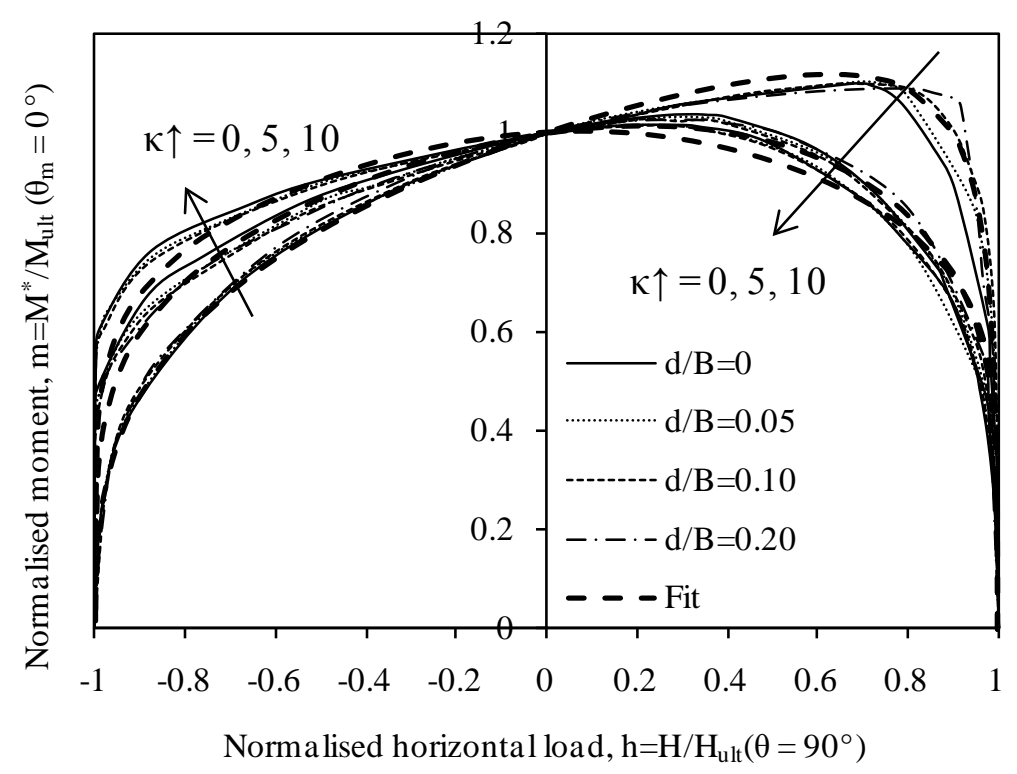

b) Effects of embedment ratio and soil heterogeneity on normalised $\mathrm{H}_{\mathrm{y}}-\mathrm{M}_{\mathrm{x}}$ failure envelopes

Figure 21 Effects of embedment ratio and soil heterogeneity on normalised H-M failure envelopes (LRP at $\mathrm{z}=\mathrm{d}$ ) 


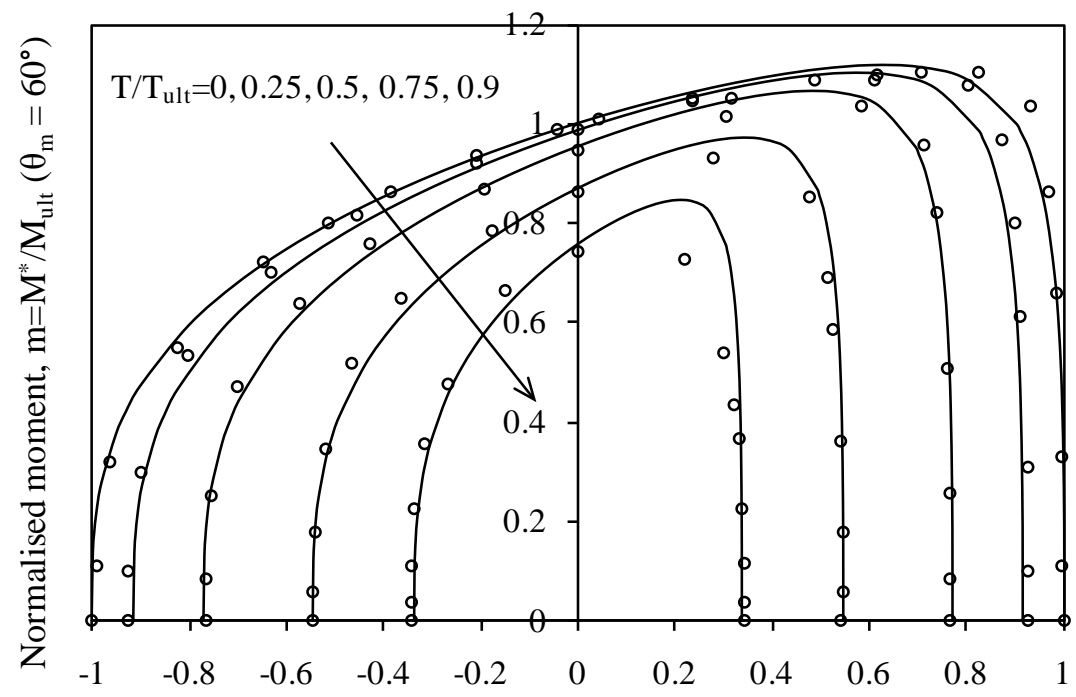

Normalised horizontal load, $\mathrm{h}=\mathrm{H} / \mathrm{H}_{\mathrm{ult}}\left(\theta=30^{\circ}\right)$

- FE results Estimation

a) Mudmat on uniform soil $(\kappa=0)$ with resultant horizontal load applied in $\theta=30^{\circ}$

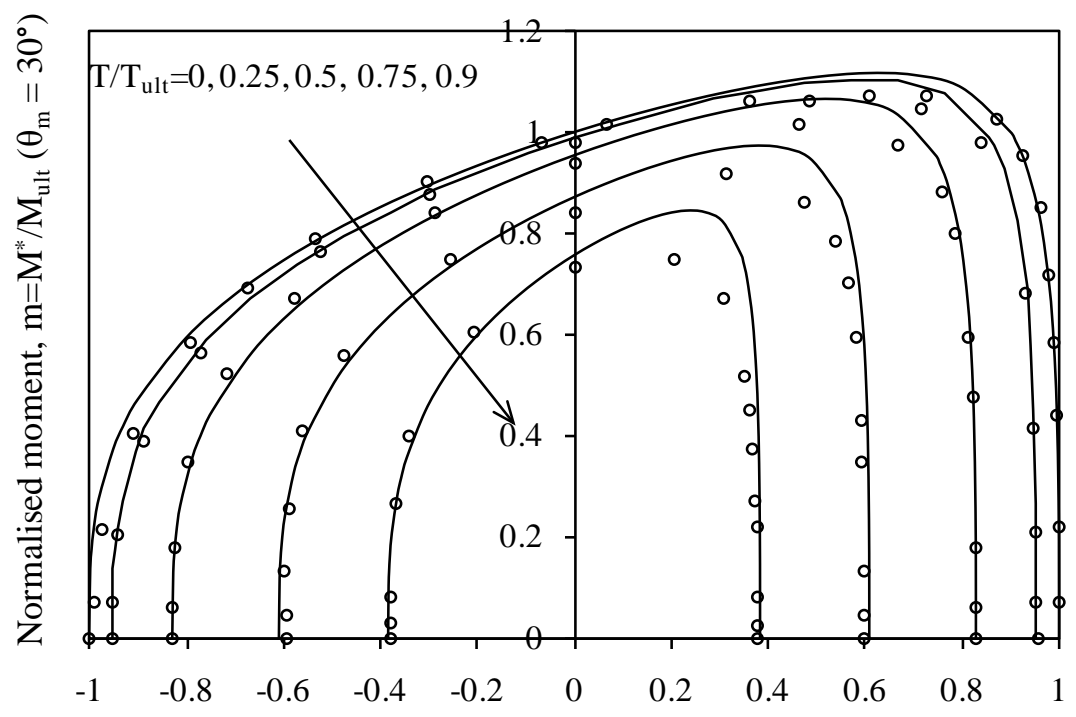

Normalised horizontal load, $\mathrm{h}=\mathrm{H} / \mathrm{H}_{\mathrm{ult}}\left(\theta=60^{\circ}\right)$

- FE results — Estimation

b) Mudmat on uniform soil ( $\kappa=0$ ) with resultant horizontal load applied in $\theta=60^{\circ}$ 


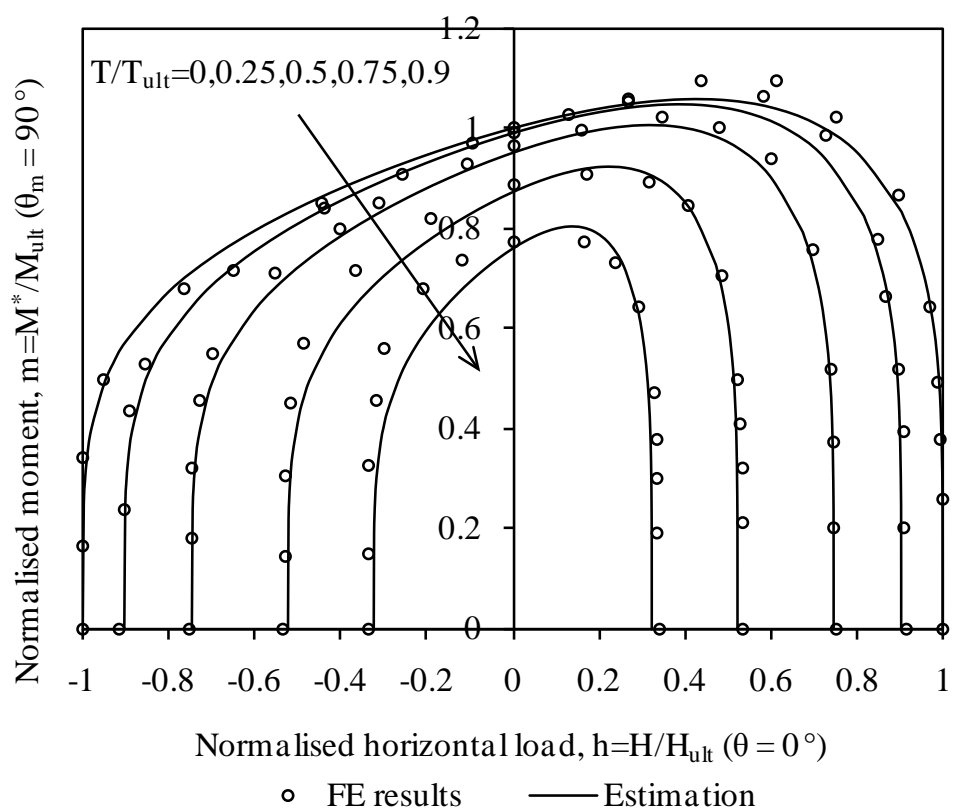

c) Mudmat on heterogeneous soil $(\kappa=5)$ with resultant horizontal load applied in $\theta=0^{\circ}$

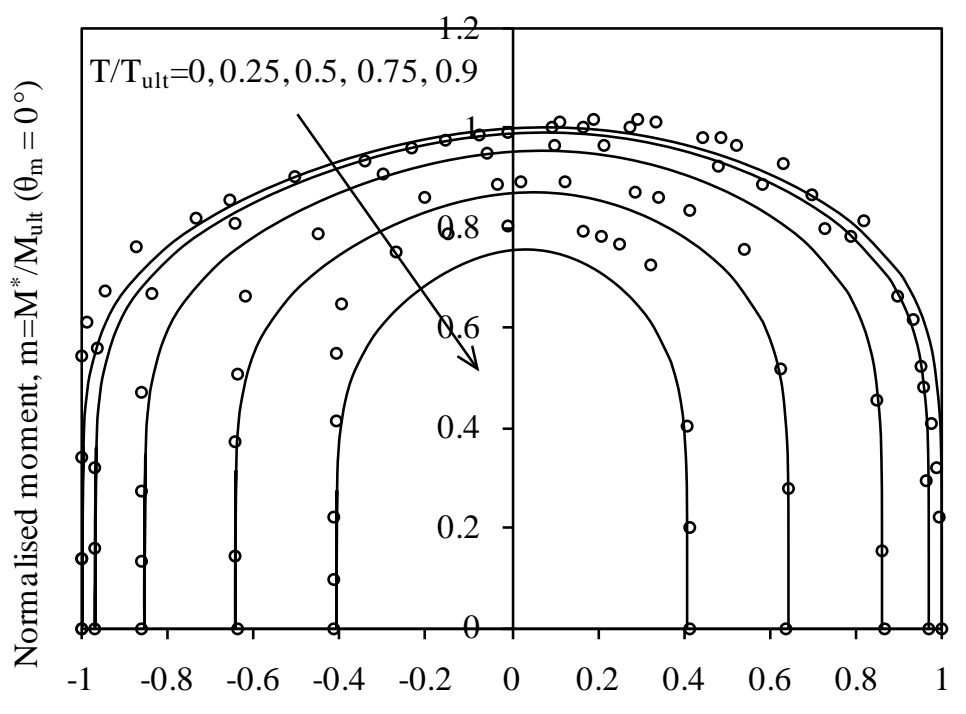

Normalised horizontal load, $\mathrm{h}=\mathrm{H} / \mathrm{H}_{\mathrm{ult}}\left(\theta=90^{\circ}\right)$

- FE results — Estimation

d) Mudmat on heterogeneous soil $(\kappa=10)$ with resultant horizontal load applied in $\theta=90^{\circ}$

Figure 22 Normalised failure envelopes for H-M loading for varying torsion 


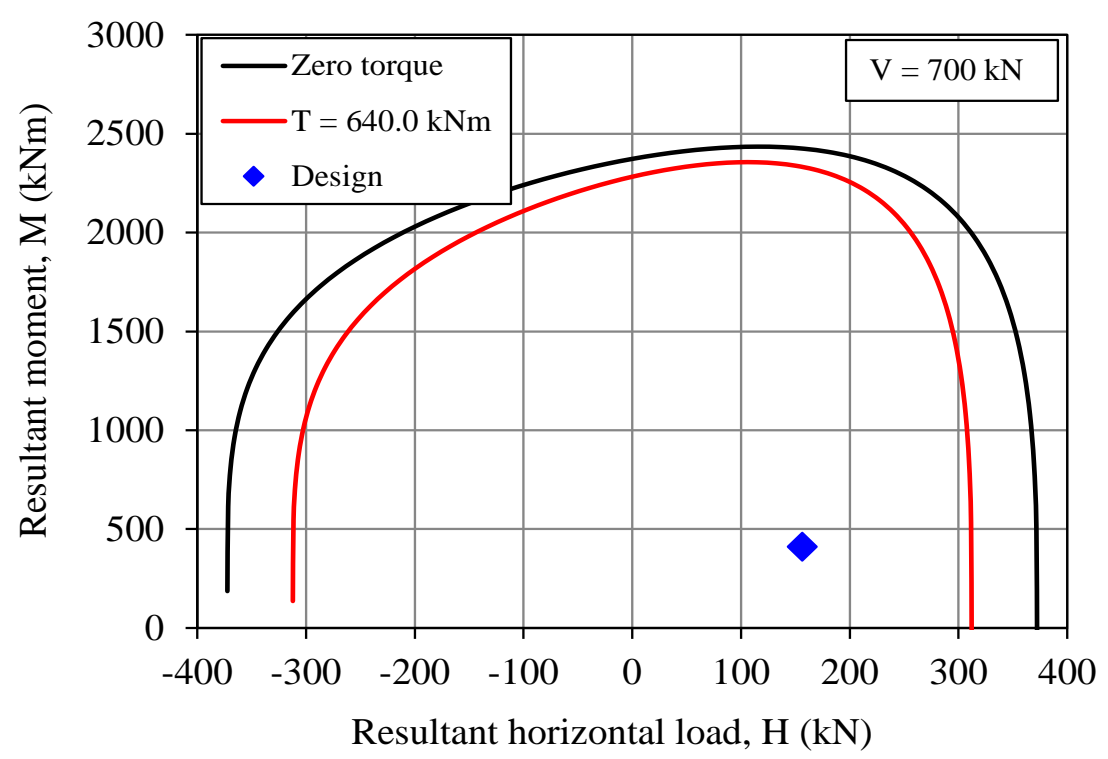

a) Unfactored shear strength data

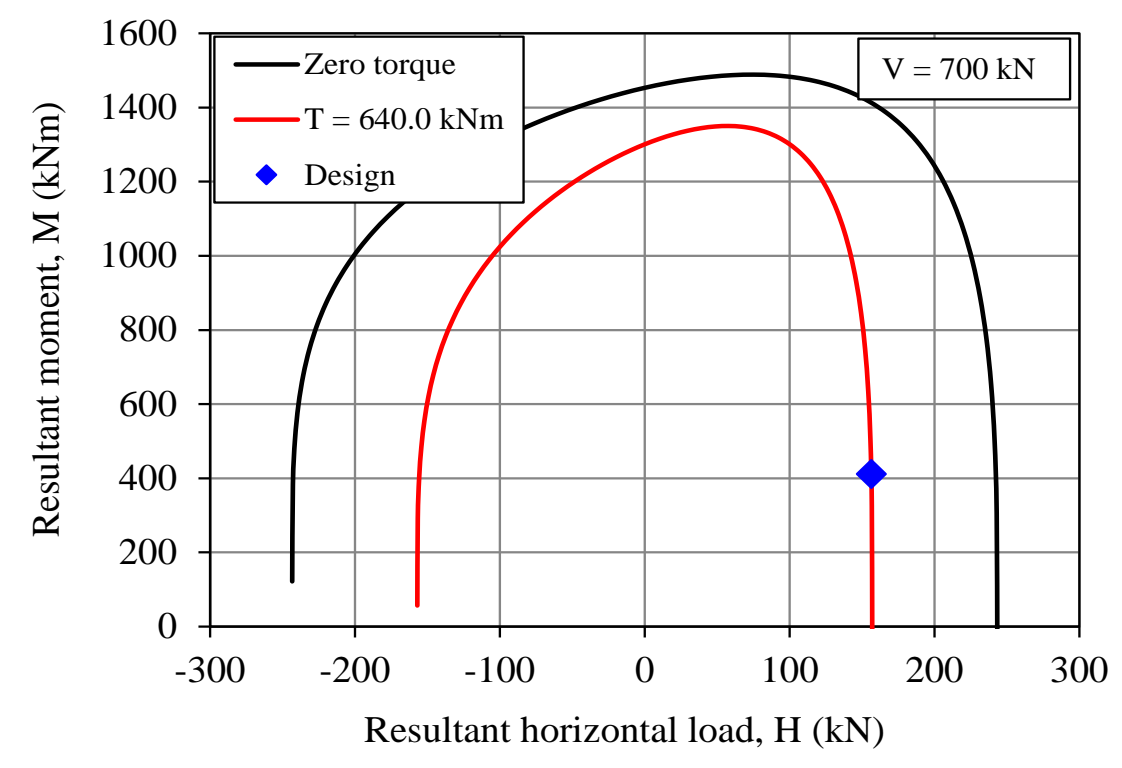

b) Factored shear strength data

Figure 23 Failure envelopes and design loading for example application 